\title{
The position of women on the Limburg labour market
}

Citation for published version (APA):

van Dam, J. W. (1992). The position of women on the Limburg labour market. Researchcentrum voor Onderwijs en Arbeidsmarkt, Faculteit der Economische Wetenschappen. ROA Reports No. 7E https://doi.org/10.26481/umarep.199207E

Document status and date:

Published: 01/01/1992

DOI:

10.26481/umarep.199207E

Document Version:

Publisher's PDF, also known as Version of record

\section{Please check the document version of this publication:}

- A submitted manuscript is the version of the article upon submission and before peer-review. There can be important differences between the submitted version and the official published version of record.

People interested in the research are advised to contact the author for the final version of the publication, or visit the DOI to the publisher's website.

- The final author version and the galley proof are versions of the publication after peer review.

- The final published version features the final layout of the paper including the volume, issue and page numbers.

Link to publication

\footnotetext{
General rights rights.

- You may freely distribute the URL identifying the publication in the public portal. please follow below link for the End User Agreement:

www.umlib.nl/taverne-license

Take down policy

If you believe that this document breaches copyright please contact us at:

repository@maastrichtuniversity.nl

providing details and we will investigate your claim.
}

Copyright and moral rights for the publications made accessible in the public portal are retained by the authors and/or other copyright owners and it is a condition of accessing publications that users recognise and abide by the legal requirements associated with these

- Users may download and print one copy of any publication from the public portal for the purpose of private study or research.

- You may not further distribute the material or use it for any profit-making activity or commercial gain

If the publication is distributed under the terms of Article $25 \mathrm{fa}$ of the Dutch Copyright Act, indicated by the "Taverne" license above, 
THE POSITION OF WOMEN ON THE LIMBURG LABOUR MARKET

Empirical findings, projects and recommendations on five aspects of women and work

ROA-R-1992/7E

J.W. van Dam

RESEARCH CENTRE FOR EDUCATION AND THE LABOUR MARKET

Faculty of Economics and Business Administration

Rijksuniversiteit Limburg

Maastricht, December 1992 
This report was written under a contract from the European Commission Task Force on Human Resources, Education and Youth, as part of the ATHENA project.

ATHENA is a research and development project focusing on the position and policy towards women on the labour market in six European regions, also commissioned by the EC Task Force on Human Resources.

\section{CIP-GEGEVENS KONINKLIJKE BIBLIOTHEEK DEN HAAG}

Dam, J.W. van

The position of women on the Limburg labour market: empirical findings, projects and recommendations on five aspects of women and work / J.W. van Dam. - Maastricht: Research Centre for Education and the Labour Market, Faculty of Economics and Business Administration, Rijksuniversiteit Limburg. - Tab.- (Report / Research Centre for Education and the Labour Market, ISSN 0922-8098; 1992/7E)

Met lit. opg.

ISBN 90-5321-098-9

Trefw.: arbeidsmarkt; vrouwen; Limburg 


\section{CONTENTS}

1. INTRODUCTION 1

1.1. Targets and structure of the project 1

1.2. The projects selected 2

2. THE POSITION OF WOMEN ON THE DUTCH LABOUR MARKET 4

2.1. Participation rate, part-time labour and unemployment 4

2.2. Educational and occupational segregation 5

2.3. Labour market characteristics of women's occupations 6

2.4. Government policy on women returning to work 7

3. THE LIMBURG REGION 9

3.1. Geographical location 9

3.2. Population and employment figures 10

3.3. Religion and cultural values 10

3.4. Economic structure 11

3.5. Industrial development policy 12

3.6. Network of equal opportunity organisations in Limburg 12

4. EMPIRICAL FINDINGS ON ASPECTS OF WOMEN AND WORK 15

4.1. Recruitment and selection 15

4.2. Affirmative action 16

4.2.1. Affirmative action schemes in companies $\quad 16$

4.2.2. Affirmative action schemes in the public sector 18

4.3. Women and technology: training and career 20

4.4. Training measures for adults and women returning to work 23

4.5. Female entrepreneurs and starting a company 24

5. PROJECTS 29

5.1. Recruitment and selection projects 29

5.1.1. Private agency for the recruitment and selection of women 29

5.2. Affirmative action projects 30

5.2.1. Cooperation between companies and childcare institutes, Stichting CBK, Central and North Limburg $\quad 30$

5.2.2. Public Bus Company, City of Maastricht 3.1

5.3. Projects in the field of women and technology 32

5.3.1. Consultancy for women and technology 32

5.3.2. Coordination of vocational technical training projects for women 32

5.3.3. Research and development project: 'Women in construction' 33

5.4. Projects in the field of training for women returning to work 34

5.4.1. Labour market re-entry of unemployed single mothers, Maastricht 34 
5.5. Projects for those starting businesses 36

5.5.1. Guidance, training and advice for female starters, Heerlen 36

5.5.2. Contact day and almanac for businesswomen in Limburg 37

5.5.3. Bureau for small-scale employment, Heerlen 37

5.5.4. Mama Cash: credit facilities for female starters 38

5.5.5. 'Mentorscope' Foundation and bureau, Haarlem 38

6. RECOMMENDATIONS $\quad 40$

6.1. General recommendations $\quad 40$

6.1.1. Regard for equal opportunity affairs in formulating regional employment policy $\quad 40$

6.1.2. A regular paragraph in the annual provincial labour market programme 40

6.1.3. Organisations for women and work should make more use of free $\begin{array}{ll}\text { research capacity } & 41\end{array}$

6.1.4. Support for a brief regional newsletter on women and work 41

6.2. Recommendations on recruitment and selection 442

6.2.1. More attention for the position of women within the provincial civil service 42

6.2.2. Business Counsellor for Equal Opportunity Affairs 42

6.2.3. Increase the supply and use of childcare facilities 42

6.3. Recommendations on women and technology 43

6.3.1. Encouragement of women and girls in technical education 43

6.3.2. Encouragement of women in technical companies 43

6.3.3. Change the public information campaign on women and technology 44

6.4. Recommendations on the training of unemployed women 44

6.4.1. Improve aggregated information on the unemployed 44

6.4.2. One integral and cooperative information and motivation campaign on women and work $\quad 44$

6.5. Recommendations on female starters $\quad 45$

6.5.1. Restructure the gathering of statistics on companies to include the gender factor

6.5.2. Special counselling hours for women with the regional Chambers of $\begin{array}{ll}\text { Commerce } & 46\end{array}$

6.5.3. Reservation of LIOF funds for female starters 46

6.5.4. Improve the orientation, guidance and advice structure for starters 


\section{INTRODUCTION}

\subsection{Targets and structure of the project}

The European Commission (Task Force on Human Resources) has asked the Research Centre for Education and the Labour Market (ROA), in Maastricht, to participate in a research and development project on the current position of women, and the policy towards women, on the labour market in the Limburg region. 'Policy' must be interpreted in a broad way, to include not only measures which are undertaken by government institutions but also projects in private companies and organisations. The goals of the project are to provide information on factors which influence the success or failure of policy measures, to describe examples of good practice which could be copied in one of the other regions, and to formulate concrete recommendations for the most relevant actors in the region of Limburg, in the five other regions involved, and for the European Commission. The project should stimulate the regional network of relevant actors and initiate new projects and measures by adopting interesting ideas from other regions. The project has been carried out by Jaap van Dam, under the supervision of Rolf van der Velden, researcher and chief researcher of ROA respectively.

One of the features of the structure of the project intended to ensure this cooperation is the "twin and braiding" structure linking the institutes which are involved in the project. During the project, ROA has had close connections with the COMETT institute of the Technische Universität Berlin. In September 1992 a small delegation of ROA and some relevant actors from the region of Limburg visited the project partner in Wales (UK), to meet the most relevant organisations. ROA itself has also hosted delegates from Berlin and Dublin (Ireland).

Cooperation was also ensured by working closely together with relevant organisations within the region. The following persons gave advice on the project:

- Dorien Hulshof, staff member and consultant on employment and self-employment issues for Women and Work;

- Secil Arda, director of Vurore (Limburg Institute for Emancipation), Roermond;

- Marjon Jacobs, staff member for policy on training and employment, Vurore;

- Esther Appelo, head of the women and international affairs section, Driekant Institute for training and conferences, Valkenburg aan de Geul.

During the project close contact was maintained with these persons. Some of them were invited to visit a relevant organisation abroad as part of the ATHENA project. As a direct result of this cooperation, ROA assisted in the development of a research programme in the area on the border of Dutch Limburg and the German Mönchengladbach region, with EC 'INTERREG' funding.

Also as a direct result of the ATHENA project, the contact officer for female starters of the 'Vrouw en Werk Winkel' of South Limburg visited the Welsh Development Agency (WDA) and the Glamorgan Businesswomen's Network. Plans were made to exchange materials, especially the Female Entrepreneur's Almanac (see 5.5.2) and the Dutch orientation course for female 
starters. Plans were also made to invite the founder of 'Mentorscope' (see 5.5.5) to one of the monthly contact dinners of the businesswomen of South Wales.

\subsection{The projects selected}

* Description alone is not enough for a project which tries to be both practice and policy oriented. The combination of research findings and information on practical measures should allow integration and assimilation and produce proposals for further policies.

* In the Netherlands, an enormous amount of research has been done on many aspects of the position of various groups of women in relation to the labour market. In a report which should be of interest to foreign as well as domestic organisations and officials the results of this research should be mentioned and integrated with information on practical measures and policies.

* Only those actions, projects and organisations which could be really interesting for equal opportunity organisations in the other regions involved in the ATHENA project, or for the Task Force and the European Commission should be described. 'Interesting' meaning that they are new and innovative for the Netherlands and maybe also for other regions, or proved to be very successful, or original and promising.

\section{Criteria for the selection of items and projects}

In the selection of projects the following considerations have played a role:

* The project should be of direct relevance for a group of women in relation to their position on the labour market.

* A distinction can be made between projects with socio-economic or employment motives on the one hand, such as those relating to the financial independence of unemployed single mothers, and projects with emancipation or justice motives, with the goal of ensuring equal opportunities for men and women, on the other hand. Both types of projects should be covered by the study.

* Attention should be given to the entrance and re-entrance of women to the labour market, but also to the opportunities for women to create their own employment. Massive unemployment cannot be cured by training for existing jobs alone. Initiatives for new enterprises are needed.

* Initiatives from both the public sector and the private sector should be included.

* It would seem that there is a kind of 'training hype' going on in the whole of Europe. In our project we pay attention only to training activities with a clear and strong relation to vacancies and the labour market. Attention should also be given to any other conditions 
$-3-$

which are necessary to improve the entrance or re-entrance of women to the labour market.

The following characteristics of the selected projects are described: the goals of the project, the starting year, the organisation, the funding, the target group and how clients are recruited, the number of participants, the project structure and success indicators.

The methods used in this project are literature and desk research, interviews and a small survey (following-up a 1989 research project among 15 companies in the Limburg region, which focused on equal opportunity measures). Those sections of this report which are based on briefings and contacts with respondents have been sent to those concerned with a request for their comments.

The final chapter of this report contains conclusions, recommendations and proposals for projects which should be initiated. Some of these proposals were discussed in sessions with regional organisations. Ideas for these proposals were also gathered during the visits to other ATHENA partners.

It is hoped that the final chapter may be useful for the Province of Limburg, Labour Exchanges in Limburg, the Regional Council on Employment Policy, the Chambers of Commerce, and organisations for women's affairs such as Vurore, LVR, LVB, the Stichting Vrouw en Werk ZuidLimburg, and the various company officers for equal opportunities. 
$-4-$

\section{THE POSITION OF WOMEN ON THE DUTCH LABOUR MARKET}

In this section we will give a description of the differences between the positions of men and women on the Dutch labour market. The information presented is partly based on another ROA report (Van de Loo \& Van der Velden, 1991). First, we give some figures on the differences in labour market participation, part-time labour, and unemployment between men and women. The second subsection explains the differences between working men and women as far as their educational qualifications and current occupation are concerned. Next, we describe the present and future labour market prospects of some typical women's occupations. Finally, we present some information on government policy towards women's re-entry

\subsection{Participation rate, part-time labour and unemployment}

Since the sixties, the percentage of women who enter the Dutch labour market has strongly increased (see Rapportage Arbeidsmarkt, 1990). This is the so-called 'participation rate'. In the past decades the participation rates of men and women have grown significantly closer. In 1960 the participation rate for men was $90 \%$ and for women $26 \%$, whereas in 1987 the figures were $76 \%$ and $44 \%$ respectively.

The participation rate of men has gone down, due on the one hand to increasing participation in education by younger men and on the other hand to an increase in the number of (older) men who are incapacitated or who retire early. The participation rate for men between 25 and 50 years of age has hardly changed. For women, on the other hand, the growth in participation has occurred especially in the middle age groups and for married women in particular. This is the 'fertile' phase of life for married women (Bruyn-Hundt, 1988).

There is a positive relationship between the participation rate and the level of education (see Van de Loo \& Van der Velden 1991, table 5.1). Especially for women, a high level of education is coupled to a relatively high participation rate. The declining participation of men is relatively greater among men with a low level of education; the increased participation of women on the other hand was relatively stronger among women with secondary and tertiary education. Despite the declining participation rates for men and the growing participation of women, the level of women's participation remains among the lowest in Europe.

It should be noted that the 'employment share' would serve as a better indicator for the female labour supply than the participation rate, because women work in part-time jobs more often than men and they are more often registered as unemployed. Thus the employment share for women is smaller than the participation rate. For example, women made up $34 \%$ of the labour force in 1983, but their employment share was only 26\% (Bruyn-Hundt, 1988). Moreover, despite the considerable increase in the participation rate among women since the early sixties, women's employment share in this period has increased considerably more slowly than their participation rate. In the 1977-1985 period the employment volume of women grew by $16 \%$, whereas the number of working women in the same period increased by over $29 \%$ (Huijgen, 
$-5-$

1989). This picture is confirmed when the weekly working hours of women working in salaried employment in 1979 are compared to those in 1985. In 1979, 56\% of these women worked in a full time job, whereas in 1985 only $46 \%$ had a full working week. On the other hand, the percentage of women working part-time increased considerably during this period.

The differences between the employment share and participation rate measures of male and female participation are determined not only by the differences in part-time work but also, in equal measure, by the differences in their recruitment and redundancy situation. For example, unemployment for women is proportionally higher than for men. It also appears that women have gained less from the recent decrease in unemployment: whereas the number of unemployed men decreased by almost a quarter between 1988 and 1990, unemployment among women decreased by only $13 \%$. This difference between the sexes is related in particular to short-term unemployment of less than one year. Between 1988 and 1990, shortterm unemployment among men decreased three times as fast as that among women, while long-term unemployment decreased for men and women at almost the same rate (Rapportage Arbeidsmarkt, 1990).

The structure of the labour market is also relevant for the position of women. Recent research into the internal labour markets of large companies and institutions (Wolfs, 1992) has shown that about $26 \%$ of the Dutch employees in the Netherlands work in an organization having an internal labour market. Places on internal labour markets are mostly occupied by full-timers and by men. Persons who work on an internal labour market generally occupy higher level jobs, with management tasks and with higher incomes, partly due to regular income increases. The job mobility within a labour organisation with an internal labour market is high, and willingness to look for external opportunities is relatively small, due mainly to the higher job security. The number of job openings is thus very small, which gives few opportunities for women to return to an internal labour market.

\subsection{Educational and occupational segregation}

Women and men often hold different kinds of jobs. This is referred to as occupational segregation. Since there is a strong relationship between education and occupation, the total occupational segregation can be split into two components. In the first place, during education, there is a pre-selection of men and women into education for different types of qualifications. After that there is a second selection process regarding occupational choice and career paths in the course of working life (Groot, 1990).

Educational segregation between men and women is related in particular to the field in which they are trained. On the one hand women appear to be over-represented in the nursing, commercial \& administrative, educational and general courses. Men on the other hand are overrepresented in the technical and agricultural fields. In 1985, with an unchanged educational structure, $19 \%$ of the active labour force would have had to change their field of study in order to neutralize educational segregation by fields. The strong segregation in educational fields 
$-6-$

therefore indicates a rather strong pre-selection process (Groot, 1990).

Occupational segregation appears to occur more in the intermediate occupational classes than in the higher or lower groups. Nevertheless it is at the lowest function level that the number of women has most increased, and from which men have particularly withdrawn. The lowest function level therefore appears to be becoming more and more a 'women's segment' (see also Elfring and Kloosterman, 1989).

The conclusion regarding the educational and occupational segregation of men and women is that an important part of the total occupational segregation has its origin in a rather strong preselection in the course of education, but that occupational segregation becomes even stronger along the career path that follows. Moreover, both forms of segregation appear to be changing only gradually.

\subsection{Labour market characteristics of women's occupations}

In this subsection we will discuss a number of characteristics of typically 'female' occupational classes, that is, occupational classes in which $60 \%$ or more of the practitioners in 1985 were women. These occupational classes are:

- medical, dental, pharmaceutical and veterinary professions and assistants;

- secretaries, typists;

- radio, telephone and telegraph operators;

- shop assistants etc.;

- cooks, waiters, bartenders etc.;

- miscellaneous domestic, geriatric care, and hotel workers;

- caretakers, cleaners etc.;

- launderers, dry-cleaners and pressers;

- hairdressers, barbers, beauticians, etc.;

- miscellaneous service workers;

- tailors, dressmakers.

In 1985 an average of $76 \%$ of the workers in these women's occupations were women, varying from $60 \%$ for the 'cooks, waiters and bartenders' to $96 \%$ for miscellaneous domestic, geriatric care, and hotel workers. In the total active labour force, $34 \%$ of the workers were women. Thus one can conclude that there were twice as many women in these women's occupations as in an average occupational class.

Of the women working in 1985, 53\% appeared to work in one of these eleven women's occupations; just six of these occupational classes accounted for $49 \%$ of the employment for women: medical, dental, veterinary, and pharmaceutical personnel and assistants, shop assistants and other sales personnel, maintenance and domestic personnel, secretaries and typists, cleaners and caretakers, and cooks, waiters and bartenders. 
The function level of these occupational classes appears to be lower than average: only one of the eleven has a relatively high function level. In accordance with expectations, the average proportion of part-timers in the women's occupations is high. For four of the eleven occupational classes the proportion of part-timers was very high. None of the women's occupations had a low percentage of part-timers.

The average proportion of self-employment in the women's occupations could be called low. Among the hairdressers, barbers and beauticians there were relatively more smaller businessmen and businesswomen. Within this occupational class however, relatively more women are in salaried employment than men (63\% versus $40 \%)$.

ROA's analysis shows that the growth in employment in the coming years will be no better or worse in the women's occupations than in all occupational classes together. The only shrinking occupational group among the women's occupations was the radio, telephone and telegraph operators. On the other hand, the demand for shop assistants is expected to grow relatively strongly.

\subsection{Government policy on women returning to work}

In 1986 the Dutch Minister of Social Affairs and Employment Policy published a draft for a policy report on women's re-entry to the labour market. It concluded that the participation of women on the labour market had grown a lot (to about $36 \%$ ), especially in part-time jobs. Nevertheless, the participation rate of women between the age of 25 and 35 remains rather low.

Proposals for policies to increase this participation rate focused on four main areas:

1. Increasing the opportunities to combine parenthood and work by means of the redistribution of labour, stimulation of part-time work and measures in the field of childcare and parenting leave. Both parents should have the right to take unpaid full or part-time leave for a period of six months, within the first two years after the birth of the child.

2. Introduction of a scheme for positive action to improve the position of working women. In the Netherlands there are still few opportunities for childcare. The withdrawal rate for women is twice as high as for men, mainly due to pregnancy. Therefore, experiments have been developed in the public sector to increase opportunities to remain within the organisation during pregnancy and in the first years after birth.

3. Facilitation of entrance to the labour market by measures in the field of education, training and career guidance activities. With the support of the government, unions and Labour Exchanges, special facilities such as the 'Vrouw en Werk Winkel' (Woman-and-Work Shop) and 'Vrouwenvakschool' (Women's Vocational Training Centres) have been established (see next chapter).

4. Increase in employment by stimulating the entrepreneurship of women returning to work. There are a relatively high proportion of 'female companies' in the areas of the personal and socio-cultural services $(46 \%)$, nutrition, textile and leather $(29 \%)$ and retail and repair 
$-8-$

services $(25 \%)$. The majority $(53 \%)$ of female self-employed are women returning to the work force. Apart from the general problems, female 'starters' are in particular confronted with a lack of training, funding, guidance and advice. On the basis of an experimental arrangement for starting female companies, facilities such as interest-free credits and tailormade advice and courses are provided by the 'Vrouw en Werk Winkel'.

Important measures are still needed in the field of income taxes and social security. The old system was largely based on the 'family' as the basic element of society. Since individualisation and economic independence have become important policy issues the system of income taxes, pensions and social securities need to be restructured. 



\section{THE LIMBURG REGION}

This chapter presents information on the socio-economic structure of Limburg, specific developments on the labour market for women and the regional network of equal opportunity organisations.

\subsection{Geographical location}

Limburg is the southernmost province of the Netherlands, with Maastricht as the provincial capital. It is bordered in the west by Belgium and in the east by Germany. There are two aspects to its geographic location:

- nationally, Limburg is peripheral as regards geographic location with respect to the concentration of employment and population in the 'Randstad' (the coastal region in the West of the Netherlands);

- internationally however, Limburg has a central geographic location in the densely populated 'Meuse-Rhine Euro-region'.

Figure 1. The Meuse-Rhine Euro-region

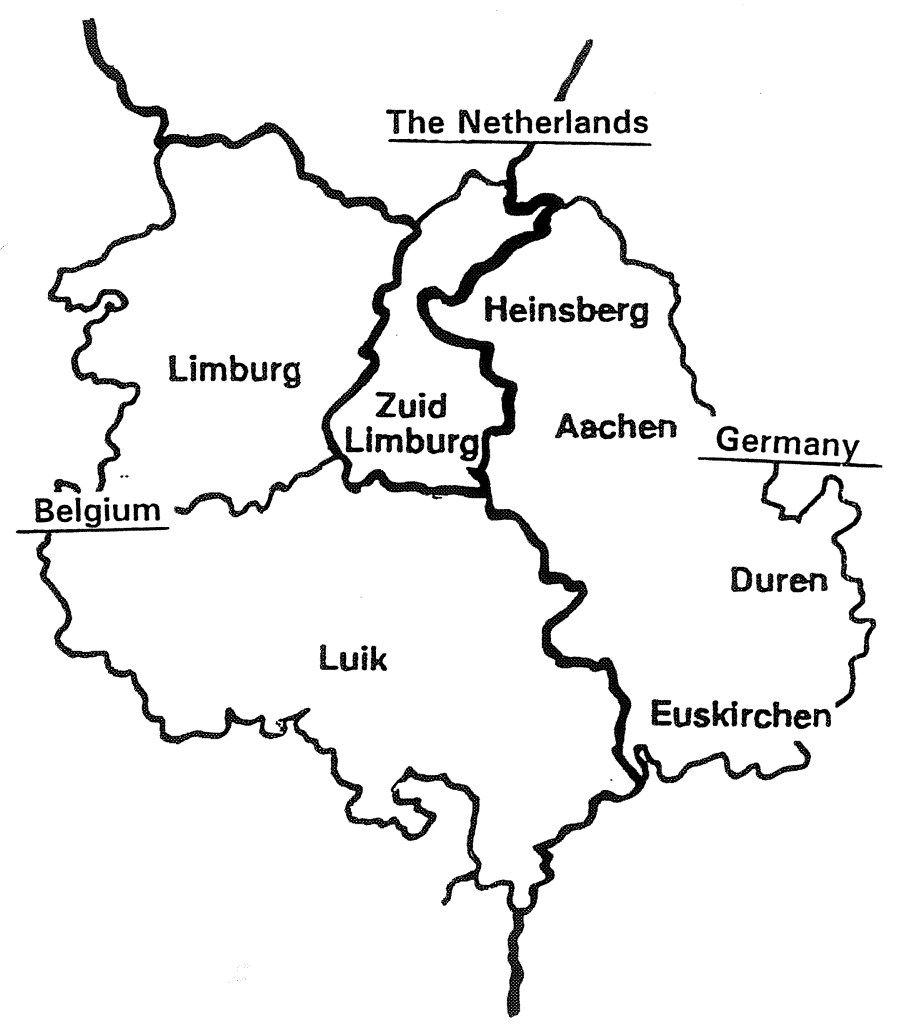


As a result, the region's economy is more internationally oriented than is the nation's economy, as is indicated by the fact that $25 \%$ of Limburg firms are engaged in export. The national figure is $20 \%$. The difference is even greater when only industrial firms are considered: here the percentage of exporting firms in the region is 10 percentage points above the national figure ( $37 \%$ versus $27 \%)$.

\subsection{Population and employment figures ${ }^{1}$}

Limburg has a population of approximately 1.1 million, accounting for $7 \%$ of the national population. This population is growing at the very slow rate of $0.5 \%$ per year (below the national average of $0.8 \%$ ) as a result of a relative low birth rate and an increasing net migration. For the country as a whole, immigration continues to exceed emigration.

As a result of past birth rates being below the national average, the population as a whole is at present aging more rapidly in Limburg than in the Netherlands. In 1987-'89 the numbers of retired people (age $\geq 65$ ) grew at an annual rate of $3.1 \%$ (the national figure is $1.9 \%$ ). This has an enormous impact on the growth rate of the age group 15-64 and consequently on the growth of the labour force. As a result of low birth rates the number of school-leavers and the rate of growth of the labour force in Limburg are declining, gradually but at a rate which exceeds the national average. The decline is not so severe because in Limburg this process has been counterbalanced by a growing immigration surplus in the last three years. In 1987-'89 the labour force in Limburg grew at an annual rate of $1.3 \%$ (nationally $1.5 \%$ ).

Over the period 1987-'89 the annual growth in the labour volume in Limburg has, at $1.6 \%$, been constantly more favourable than the national growth rate $(1.2 \%)$. As a result of this growth in the demand for labour and the declining growth of the work force, the total unemployment level in the region, which exceeded the national average at the beginning of the $80 \mathrm{~s}$ had declined to $8.2 \%$ in 1991 (the corresponding national figure was 8.7\%). Since 1983 both the level of unemployment and the proportion of long term unemployment in the region have declined constantly. However the reduction in regional unemployment has been more favourable for men than for women. In 1989 regional female unemployment (18.7\%) still exceeded national female unemployment $(17.0 \%)$.

\subsection{Religion and cultural values}

Several studies have tried to describe aspects of the typical Limburg culture (Felling and Peters, 1988; Schreuder, 1989). The Province of Limburg has a long-standing catholic tradition. According to Soeters and Felling (1990), this implies a large role for faith in God, which makes life more joyful and light-spirited than the Protestant way of life. Tradition, habits and togetherness are more important than conscience, conviction or personal insight. The result is a

1. This section is based J.W. van Dam, G.W.M. Ramaekers, R.K.W. van der Velden, Skill Shortages in Limburg, ROA-R-1991/3E, Maastricht, 1991. 
traditional view of marriage and the role of women in the family way (Soeters and Felling, 1990).

The collective character of the modern Limburg culture also makes the region very suitable for the foreign, and especially Japanese, investments that have been made in the last few years. From other research, it is known that Japanese companies have been very successful in SouthWest Wales, a former mining area in many respects similar to South Limburg. Similar conclusions were drawn in the United States where Japanese investments were more successful in the rural south, with its community spirit, than in the north with its more individualistic way of living (Hofstede, 1987).

\subsection{Economic structure}

In the first half of this century the Limburg economy was dominated by coal mining. In 1965 the Dutch government decided to close the mines which were public enterprises. As a result the economic base of the region has, since the mid-sixties, shifted radically from coal mining to manufacturing. This process of economic change has been stimulated by an active economic restructuring policy on the part of national and regional governments.

The following sectors dominate the region's economy, both with respect to production value and employment:

- the chemical industry;

- the manufacture of metal products and machines;

- construction and installation;

- the retail and wholesale trade;

- public services.

These sectors account for $44 \%$ of the region's production value and $48 \%$ of the working hours in Limburg. Except for the chemical industry and public services, these sectors are all confronted with hard-to-fill vacancies. In research by the Limburg Chamber of Commerce in $1991,14 \%$ of enterprises reported that they were confronted or expect to be confronted with hard-to-fill vacancies, of whom the construction and installation sector $(30 \%)$ and the metal industries $(27 \%)$ claim to have the highest rates. Other branches with difficulties were: hotel and catering $(13 \%)$; commercial services $(13 \%)$; and retail trade $(10 \%)$.

Since 1983 the region's economy and the number of hours worked have been growing at a faster rate than the nation's economy. Industry and building activities are growing at a rate above the national average, and industry is more important for the region's employment than is the case for national employment. Limburg benefits from activities such as the manufacture of building materials, the chemical industry, the printing and paper industry and the transport and communication sector, all of which rapidly grew in recent years. These activities are more highly concentrated in the Limburg economy than in the nation's economy. 


\subsection{Industrial development policy}

The 'Industriebank LIOF Ltd', the Limburg Industrial Development Fund, is a bank for the industrial development of Limburg. It is an important tool for regional industrial development policy. It has an equity of about 120 million guilders and a development fund of about 1.3 million guilders yearly, which can be used for several innovative projects. The funds are managed by a board of trustees who are appointed by the national Ministry of Economic Affairs. Because it is not a part of the public sector, LIOF does not have a fund reserved for the financial support of starters. This support, in the form of shareholdings and risk-bearing loans, is part of the general reserve. Since autumn of 1991 the support of starters has been part of the policy of LIOF. At the end of 1991 LIOF held shares in 34 companies, with a total value of 18 million guilders.

An important criterion in choosing investments is the kind of business in which the starter is active. The main sectors are the industrial or handicraft sectors, and business to business services. LIOF tries to operate as a secondary support service, with the Chambers of Commerce, the private banks and the Regional Centre for Small and Medium-size Enterprises as gatekeepers in the first line. In addition to financial activities, LIOF organises seminars for junior and senior starters.

According to the 1991 annual report, LIOF is worried about the number of starters in Limburg, which is lower than other parts of the Netherlands. Some initiatives have been developed to support starters. Firstly, the provision of a 'Starters' Fund'. Because this is a part of 'general funds', it is not possible to give a total amount for this starters' fund. At the moment LIOF has contacts with about 20 persons who have started a company and are looking for share and loan equity.

\subsection{Network of equal opportunity organisations in Limburg}

Apart from a large number of organisations working in the field of equal opportunities for women on a national scale (such as public bodies and councils, trade unions, private institutions) there is also a network of several regional organisations:

The Provincial Government of Limburg: compared to other provinces, this province does not play an active role in the field of equal opportunities. In 1989 a report on the internal (within the organisation) and external equal opportunity policies of the Province was prepared. In practice, however, this report has not brought about major changes. In the Provincial Administration, out of a total staff level of 740 f.t.e workers, only 1 person is employed to dealt with internal and external equal opportunity activities. Of a total budget of 550 million guilders, provincial expenses for equal opportunity measures are about 1 million at present. Of this amount, $60 \%$ is reserved for SPEL (see below). The other 0.4 million is for subsidies for a large range of projects for women. The Deputy for Women's Affairs has meetings with equal opportunity organisations, such as SPEL, Vurore, LVR and LVB, twice a year. There is also a 
$-13-$

formalised consultative structure linking all of the organisations who work on women issues (PEN: Provinciaal Emancipatie Netwerk). This network has several sub-groupings.

SPEL (Stichting Provinciaal Emancipatienetwerk Limburg): founded in 1986 and located in the city of Roermond. This foundation is in large part supported by the Province of Limburg. Its major goals are the stimulation and improvement of equal opportunity policy and measures in Limburg. Attention is especially directed towards women's organisations, local governments and political parties, to whom information and advice are supplied. SPEL also provides courses on politics and society. Main products: list of addresses of all organisations and officers in Limburg involved with equal opportunity policy, and the SPEL vacancy-bank;

Vurore (Instituut voor Emancipatie Ontwikkeling Limburg): founded in 1986 and located in the city of Roermond, Vurore grew out of the progressive, equal-opportunity oriented women's liberation movement. This is one of the 15 Equal Opportunity Agencies in the Netherlands, supported mainly by the Under-secretary for Women's Affairs with the Ministry of Social Affairs and Employment. Attention is especially focused on employment and training. In the near future, financing of this institute will be taken over by the provincial government.

LVR (Limburgse Vrouwen Raad): this is an umbrella platform for almost all of the organisations on women issues in Limburg, grouping 22 organisations with 23,000 members. The LVR was founded in 1975. Its main goals are the emancipation and education of women and the integration of women in all aspects of society. It tries to do this by representing the organisations and all of their members. One of the main issues is women and work, with the unification of Europe and the new opportunities for women as topics for 1991 and 1992. A magazine is produced, and various conferences and meetings have been held.

LVB (Limburgse Vrouwen Bond): the LVB is part of the Union for Catholic Farmers' wives in the Netherlands. The LVB has 13,000 members and is especially focused on the various aspects of the life of a farmer's wife. In recent years attention has been given to women and work.

Vrouw en Werk Winkel: centre for the support of women and work. Located in Venlo, Heerlen and Maastricht. In the Netherlands there are 36 of these organisations, subsidized by the Regional Employment Boards. They have consultation hours to provide information and advice and to develop a structure for further guidance on training and employment. Training courses for women are given in the fields of 'Vocational Guidance', 'Starting your own company' and 'Women in technology'. The activities of the V\&W-winkels were evaluated in 1990 as part of the subsidy arrangement. Some of the reasons for their success were found to be the V\&Wwinkel's low threshold character, individual guidance, specific knowledge in women's issues and regarding women returning to the work force, and the link made with the experience of the clients. Clients reported increased self-confidence and motivation. Therefore the V\&W-winkel is especially useful for those women who have serious problems with finding a suitable and sufficiently well-paid job. 
The Regional Employment Board for South Limburg: has an officer who is especially involved with Vocational Training for Women (Vocational Training Centre, Heerlen). Despite all efforts no Vocational Training Centre for Women has thus far been established. Instead the Province, together with the Employment Board and the Vocational Training Centres in Limburg are financing this three-year appointment, which is largely based on the concept of the Women's Vocational Training Centre (see also chapters 4 and 5 ).

FNV Trade Union, organisation for Women's Affairs: the FNV is the largest trade union in the Netherlands, with about 1 million members. There is a sub-organisation for women's affairs for the Netherlands as a whole which, for example, lobbies parliament and government departments regarding legislation which could affect the labour market position of women. In many regions, including Limburg, the FNV Women's Affairs Organisation has a group of volunteers who could be very important in supporting actions within companies.

Emancipation Officers of public administration bodies. Almost all the larger public administration bodies such as municipal and civil services (police, fire brigade), provincial government and the universities have equal opportunity officers and a paragraph in their annual report or a special policy report on the item of equal opportunities and women's affairs. Some of the larger companies also give attention to equal opportunity issues (see page 15). 


\section{EMPIRICAL FINDINGS ON ASPECTS OF WOMEN AND WORK}

In this chapter we give an overview on some research findings on selected items relating to women and work. These items are related to the projects which will be described in the next chapter. This chapter therefore serves as a general introduction to these projects.

\subsection{Recruitment and selection}

Women are faced with unequal chances in many aspects of the procedures for the recruitment and selection of new employees. In the Netherlands, some research has been done in the field of the recruitment and selection of new employees.

In Van Beek (1992), the preferences of a panel of 312 employers (respondents) for employee personality profiles are measured by means of conjunct-measuring. The personality profiles consisted of 12 variables, such as gender, age, health, ethnic background, education, current labour market position, availability, family background, and working experience. Preference rankings and combinations were recorded for these variables, together with background variables such as which industry they were engaged in.

It was found that employers think and say that they pay attention to skills such as education and working experience in particular. In practice, it was found that they strongly select for personal characteristics such as age, health, gender and race.

The employment policy of the government is directed especially at improving the supply side of the labour market by training the unemployed. But in the perception of the employers, ascribed productivity is indicated by the 'easy' indicators mentioned above. Therefore, according to Van Beek (1992), government policy should be more directed at intensive and individual training and guidance for the unemployed and at the perceptions and attitudes of employers towards women and ethnic minorities. This could be done by an Employment Equity Act similar to the Canadian model.

Other large scale research has also shown the differences between recruiting channels for men and women. Recruiting channels can be formal (reaction for vacancy announcement, mediation by employment agency or labour exchange), informal (family, relatives, training periods or school), or by a private initiative. Braams en Meesters (1991) showed that technically trained women often use the formal ways $(q=54 \%, \delta=33 \%)$ while men often use the informal ways (43\% for men vs. $27 \%$ for women). Links established through school and training are especially important for men. These results are proved by other large scale school-leavers surveys such as RUBS (Registration of outflow and destination of school-leavers). It should therefore be noted that schools need to be very careful in selecting a company for practical training for a girl from technical education. 
The influence of sex stereotypes was also studied in a recent field study by Van Vianen and Willemsen (1992). The employee selection process for higher level technical and academic jobs in real life situations was studied, with special attention to the assessment of applicants by members of selection committees. It was demonstrated that, according to the job interviewers, the ideal applicant had more masculine than feminine traits. Males and females were regarded as having the same qualifications for the job, but because male applicants were assessed as having more masculine characteristics and female applicants more feminine characteristics, the male applicants were accepted more often. The job interviewers acted according to a fit model: the applicant most similar in traits to the ideal applicant was hired for each job.

\subsection{Affirmative action}

\subsubsection{Affirmative action schemes in companies}

Improving the situation and position of women within companies is one of the most difficult issues of women's emancipation. In countries such as Canada, the United States of America and the Nordic countries, it has been shown that equality acts are necessary to force companies to take the situation of female workers into account. In the Netherlands, the central government has reached an agreement with the social partners to improve the position of women on the labour market (Gemeenschappelijk Beleidskader, December 1989).

Two research projects were initiated by the Ministry for Social Affairs and Employment Policy (SoZaWe, 1992):

1. The Department for Collective Labour Agreements (CLAs) analysed 168 Collective Labour Agreements (of the year 1990) for the presence or absence of equal opportunity measures within companies.

2. The Department for Wage Affairs analysed the practical performance of the CLAs mentioned above, within a sample of 842 companies and institutes. Within these companies, interviews were held with a personnel manager.

Both research projects were directed at the following topics: affirmative action, parenthood and paid work, facilities for working women (in case of pregnancy and childbirth) and sexual harassment.

In more than $50 \%$ of the CLAs in 1990 special attention is paid to the position of female workers within the employing organisations. In only 8 of the 168 CLAs was there a comprehensive policy scheme for affirmative action: these can be found in the banking sector and some multinational companies. Another 79 CLAs, especially the larger ones, contain some reference to the position of female workers. A major part of these are only intentions to develop measures. This is, by the way, an improvement as compared to 1988, when only 36 CLAs contained such intentions to introduce measures. In 81 of the CLAs there is no special reference to women's issues: these CLAs are found in the agricultural, construction and transport sectors. 
Concrete measures in CLAs include employment and training projects for women returning to the work force, and the duty to report on equal opportunity issues. But only one CLA contains a quantitative target for the male/female ratio of employees.

Only a minimum of provisions with regard to pregnancy and child birth are found in Acts such as the Health Insurance Act, the Labour Act, and the Working Conditions Act. They provide regulations for the working conditions of women during pregnancy and a minimum fully-paid leave of absence of 16 weeks during the period before and after childbirth. Conditions are stipulated in the Collective Labour Agreements between employers and employees. Three main categories of conditions can be distinguished:

1. The length of the leave of absence before and after birth: there are regulations on this issue in about $50 \%$ of the CLAs.

2. The possibility of flexibility of the leave period (during pregnancy and/or following the birth).

3. The possibility of additional paid or unpaid leave.

In the research on the practical consequences of the CLA regulations it was found that all companies say that they are familiar with regulations on pregnancy and childbirth. About two thirds of the companies do not provide information in an active way, but only when an employee asks it. One third of the companies, especially in the service sector, provide written information. Almost $60 \%$ of women return to their job after they have given birth. This ratio is a bit higher in the service sector than in industry and agriculture. In only a very small portion of the CLAs are measures included for lighter working conditions during the pregnancy period. The larger companies in the service sector in particular have some regulations such as regular working times and possibilities for extra rest periods. Other measures such as adjusted or changed tasks, couches, or possibilities for breast feeding are very rare.

In the 1988-1992 period the number of CLAs with a paragraph of measures in the field of childcare increased enormously, to $43 \%$. However, in practice, in only $15 \%$ of the 842 companies within the survey sample were practical regulations for childcare found in 1990 . The most important reason for organisations in the service sector taking these measures is to keep women from leaving work. The strongest motivation for the companies in industry and agriculture are the obligations contained in the CLA. Other motives are the positive image of the company and as a way to increase the recruitment of young women. In $87 \%$ of these companies, especially the larger ones, the employees have to pay a part of the costs of childcare. In half of these companies this contribution is income related. Most of the companies (67\%) have bought some places in the local childcare centre. In $28 \%$ of the companies the employee has to search for a vacant place, while the company gives financial support.

In a recent study among parents and employers regarding the supply and demand for childcare facilities (OSA, 1992) it was found that in the Netherlands, apart from the health care and welfare sector, employers almost never provide internal facilities for childcare. More employers have arranged external facilities or provide individual support, especially in the public services $(32 \%)$, education $(11 \%)$ and commercial services $(10 \%)$ sectors. Employers in industry, 
agriculture, construction, trade, catering and transport arrange almost nothing. It was found that large employers with many female employees have the greatest supply of organised childcare facilities. Thus it seems that the supply of facilities is closely related to the number of working women.

Other, non-organised forms of childcare are much more important, as can be seen from the results of a large phone survey among 3,600 women (Maassen van den Brink, 1992). Of these women, $55 \%$ are performing paid work and $45 \%$ have unpaid work, for example in housekeeping. More than three quarter of the 1,940 women with children have informal ways (family, relatives, friends) of taking care of the children. Only one quarter are using more formal types of childcare (nurseries, au pairs or paid baby-sitters, or proxy parents). Of the women with paid work almost $60 \%$ use a formal type of childcare.

In general, the use of institutes for childcare is very small: only $2.3 \%$ of mothers with young children use a subsidized childcare institute, and only $1.4 \%$ use a private establishment. In practice, the importance of other formal but unorganised methods (proxy parents, paid babysitters) is much greater.

For the women who were interviewed, the price of childcare plays no role. Thus the current government policy to promote childcare by subsidizing the costs is probably not very effective. Apart from this, according to many of the respondents, little children need a lot of love and attention. Therefore, many parents prefer baby-sitters or au pairs instead of the more official and professional childcare centres. This form of childcare has however one great disadvantage: the risk of being unexpectedly let down by the baby-sitter so that the working mother has to stay at home.

The researchers suggest that the government should give a higher income-tax free level for young mothers, instead of the present subsidies or income tax reliefs for childcare. This gives a free choice for the parents.

\subsubsection{Affirmative action schemes in the public sector}

As a large employer the government has the opportunity to serve as an example in the field of affirmative action and to influence the cultural climate for equal opportunity issues. In 1990 about 40,700 women worked for the central government, mostly in ministries, accounting for $27.5 \%$ of the total number of employees $(=148,000)$. The percentage of women has grown in all age groups, but especially in the category of 25-34 years. This growth was largely due to a high exit rate of young men. The proportion of women has grown especially in the highest income levels. Compared to men, women were also promoted more often, at a younger age, and after a shorter working time. (Ministry of Home Affairs, 1991).

As part of the policy on organisational and personal issues of the public sector, schemes for affirmative action have been developed and introduced. There are projects in police, public 
$-19-$

transport, and the fire services, among others. Evaluation studies have been undertaken especially in the police force.

In 1985 the Secretary of State for the Interior (Police and Fire Services) determined that the proportion of female police officers should be $25 \%$ within a period of ten years. After a (midterm) intermediate evaluation (and a quantitative survey) the Police Equal Opportunity Commission (LPEC, 1992) concluded that it would be impossible to reach this goal. At present women constitute $13 \%$ of the police on active duty. In the higher positions this is only $2 \%$. In addition to this vertical segregation, there is also horizontal segregation: few women work on criminal affairs, detective work and intelligence, but many in basic surveillance, administration and domestic affairs.

Reasons for women to avoid police work are, according to the Commission, the macho culture, and a lack of supporting conditions such as structural career planning, opportunities for parttime work, and childcare facilities.

Career planning: only a few units have opportunities for career guidance by means of advisory talks and career training courses.

Part-time working: since 1985 part-time work has officially been possible. In every police region an average of 18 persons are working on a part-time basis; 15 of them are women, all of them working in the lower executive functions and in administrative work. Many police units have a policy that part-time work is not possible for the higher positions. For many women, this is a constraint when considering applying for a higher position.

Sexual harassment: more than a half of the units think that there is no sexual harassment within their team. Three quarters of the units don't have a procedure or a commission to deal with harassment. Despite this, there have been 21 official complaints by women.

Childcare: only one unit has an internal childcare centre. One quarter of the units have arrangements with external institutes for childcare. For almost half of the women who leave their job, this and the intention to have more children are the reasons.

Jacobs et al (1990) have done research on the recruitment and selection of women for police work. As a result of this empirical research among 144 city units, they concluded that coincidence and factors related to the particular police unit and the personality of the recruiter in a selection process are of much greater importance than the characteristics of the candidates. There is no systematic prejudice for or against women: the number of men or women appointed is strongly related to the numbers available in the recruitment phase. Therefore, it is very important that a relatively large number of women present themselves in the selection phase. Some reasons why the official target rates will not be reached are that the supply of suitable women is too small and competing organisations such as defence, customs, and the penitentiary system are recruiting the same kind of women; if women were to occupy all the traineeship positions, the number of traineeships would have to triple, since the average career of women is expected to be 8-10 years compared to 30-40 years for men; if the vacancies are filled by women and ethnic minorities (another target group of public policy) in 
order to reach the target rates, men would be excluded from a whole cohort of the police. Resistance to women in the police force may also stem from arguments like: women are too emotional, they lack physical strength, or the marriages of policemen could be damaged by the presence of female colleagues. However, these arguments do not play an important role in the actual selection process.

\subsection{Women and technology: training and career}

In the Netherlands, a very small portion of technical occupations and jobs are occupied by women. Both from an equal opportunities point of view and considering labour market shortages in technical fields, the government is trying to encourage girls to choose a technical education. Nevertheless, the path to a technical career is a narrow one for girls. Many problems arise along the way, during the school career as well as during the professional career. The question is, what are the causes for these problems and when do they arise? In a recent research (Braams and Meesters, 1991) the following questions were investigated:

1. What factors influence girls' choice of a technical education?

2. Are there any specific characteristics in the school careers of girls who choose technical education?

3. What are the characteristics of the first phase of the labour market career of these girls?

4. What are the prospects of girls in technical occupations?

Two data sources are used for the analysis. Firstly, secondary analysis has been performed on the results of a large scale school-leavers survey by the Dutch Central Bureau of Statistics. Out of the original sample of over 37,000 pupils, only a few hundred girls ever started in technical education and only 35 have graduated in lower technical education (LTE) and 21 in intermediate technical education (ITE). Secondly, new data has been collected. Telephone interviews with a little more than 150 girls with intermediate technical education and personal interviews with 80 of them have given a wealth of qualitative information about how girls manage in a technical environment. In addition, 10 employers have been interviewed.

The results and conclusions can be summarised as follows:

- Girls in lower technical education (LTE) mostly have a background with parents who either do not work or who have quite high-level occupations. They are more to be found in cities than in the country. The choice for LTE seems to be a non-conformist one. The school career of LTE girls can often be called problematic. The LTE girls need more time to find a first job after leaving school than boys. They also work in different sectors: boys work mainly in industry and construction, girls more in trading and repair companies. Girls usually work in lower level and more poorly paid jobs than boys with LTE.

- The girls in intermediate technical education (ITE) also come from a higher social and educational background than the boys. They also have a higher achievement score, which is partly due to the fact that girls are more likely than boys to enter ITE via lower and intermediate general education instead of lower vocational (technical) education. Girls enter 
ITE at a later stage than boys do. When they are in ITE, their school career is like that of boys. Almost the same success rate is reached. As in other cases, however, girls more often stop with education when they graduate, while boys tend to continue with a higher type of education. Generally it takes more time for ITE girls to find a job than for boys. Three years after leaving school girls have a higher job level, but earn a lower net wage. The labour market position of ITE girls is better, compared to equivalent boys, than the labour market position of LTE girls.

The research of Braams and Meesters also had a qualitative part with interviews with 80 ITE girls working in a technical occupation. Half of the girls had a clear and strong personal motivation for choosing technical education. The other half was led by the advice of others or ended up in ITE more or less accidentally. Compared to boys, girls are more attracted by the contents of the education, while boys are more attracted by favourable labour market prospects. The advice of the school they attended previously is very important for girls, for boys the advice of parents and family is more important. One out of four girls experienced no encouragement at all for her choice for technical education. The others were encouraged by one or both of their parents, especially fathers with a technical background, or by the previous school. It is however, clear that not all parents are happy with the choice of their daughter. ITE gives girls a tough time. They all need some time to find their place among the male population of the school. The attitude of boys and teachers is sometimes negative. The practical learning period is also often a harsh confrontation with a girl-unfriendly reality. Despite these problems the school careers of girls do not differ very much from those of boys.

About $70 \%$ of the ITE girls enter the labour market directly after leaving school. The first phase on the labour market is often a little problematic: girls need more time to find a job which matches their education, which is amazing given the shortage of technicians. The girls themselves think that employers have a problematic attitude towards women in technical jobs, the employers deny this quite strongly. ITE boys and girls are found in different occupations. The girls' jobs are often of a supporting nature: designer, process operator, technical commercial or administrative functions. Boys are found more in directly production-oriented jobs. Part of this difference can be attributed to differences in educational fields and to the fact that girls have followed general education prior to ITE, while boys have more often followed LTE prior to ITE. The difference can in part be linked with the belief that women are more gifted with traits such as accuracy, patience, client orientation and the like. Despite all problems during the school and occupational career, many girls eventually find their place on the labour market and have outspoken ideas of what they want to achieve. Most of the interviewed girls want to keep on working when they have children, but for technical women as for other women, this will not be easy. Because of the lack of facilities to combine children with work, the position which these technical women have achieved with such difficulty becomes uncertain again.

The overall impression is one of a knock-out competition: at an early age differences between boys and girls begin to appear and, at certain specific moments, girls drop out of the flow towards a technical occupation. The girls who survive are only a fraction of those who initially 
had the capacity for a successful technical career. The potential is enormous, but only a few finally reach the end. Girls first drop out of the flow in their initial education. Girls have a lower performance in arithmetic, due to socialisation processes at home and at school. Arithmetic skills are at a later stage very important for the choice of 'hard' subjects in general secondary education. The next fall-out takes place at the end of general secondary education: even when they have the required minimum of 'hard' subjects (two), girls very rarely enter intermediate technical education. When they do, they generally have a hard time during school and especially during the practical learning period. Once they have graduated, girls take longer to find a suitable job than boys, even while there are notable shortages of technical personnel on the labour market. Finally, women are often forced to give up their jobs, because there are insufficient facilities for combining parenthood with work.

The research project of Braams and Meesters will be followed up. The 80 women with an ITE education and a technical profession are highly motivated: more than $70 \%$ want to stay in their job when children are coming. Nevertheless, employers expect the women to stop working. In most companies there are no facilities to enable them to combine children and work. To find out how women deal with this dilemma, a longitudinal follow-up study is planned. The 80 women will be interviewed by phone, four times at intervals of six months.

In 1988, Vurore undertook an inventory of equal opportunity measures and policy in 16 large Limburg enterprises (Claassens, 1989). In 1992 a follow-up study was undertaken by ROA in cooperation with Vurore. In this follow-up only seven out of the 16 companies returned the questionnaire. In the 1988 survey, most of the selected companies had already undertaken some measures to improve the situation of women in the company. Nevertheless, the few women who work in these companies are concentrated in a few occupational groups at lower function levels. For almost all companies, improving the business results is the only motive for these equal opportunity measures, for example because lack of trained personnel is making it difficult to ensure the quality of the product.

The research institute ETIL investigated the position of women in 36 metallurgic companies in the Province of Limburg following the 'Women in Metallurgics' project. With $28 \%$ of the labour force, metallurgics is one of the most important industrial sectors in Limburg (Van Camp, 1991). Compared to the Netherlands as a whole, there are less women in Limburg following technical education, but there are relatively more working in a technical job. Women's interest in a technical career has risen in the last five years. On the other hand, companies are also more interested in female workers, driven by the labour market situation. Out of 35 companies, 16 had women in technical positions and another 13 had experience with women technical workers. Almost all of the companies were very satisfied with these women. The project 'Women in Metallurgics' has shown that metallurgic companies are very interested in technical women and that the women can be very useful for them. One of the major problems in the project was the recruitment of women willing to participate in the project. This proved to be more difficult than the recruitment of companies. 


\subsection{Training measures for adults and women returning to work}

In a recent research project the output and efficiency of eight types of educational institutions for adults has been evaluated (De Koning, 1991). Despite the poor availability and comparability of figures on efficiency, it seems clear that the effectiveness of training measures initiated by the Employment Board varies between $40 \%$ (for projects directed at low opportunity groups) to 90\% (Kaderregeling Scholing (KRS) and Women's Vocational Training Centres). In all cases effectiveness is defined as the number of students that graduate from the training course. In general, the researchers conclude that training activities are more effective when the previous educational level of the participants is higher and the duration of the courses is shorter. The most important reasons for students to discontinue a course are the level of difficulty, problems in combining work and training, or the acceptance of a (full time) job.

The most important training institutes in the public sector are the Vocational Training Centres for Adults (CVs), part of the Regional Employment Board. There are now about thirty centres in the Netherlands. They provide sixty courses in the fields of construction, metallurgics, clerical work and services. The capacity of most of the centres is reduced because of the limited number of course places, traineeships and vacancies. Success rates in terms of the proportion of participants who finish the course and job placement are very high, especially in the field of services. These success rates are largely due to high standards in the selection phase.

One of the most successful training instruments is the Kaderregeling Scholing, established in 1987. It has two goals: to stimulate the training of unemployed persons (by the Labour Exchange) to increase their chances on the labour market, and to stimulate training of those already employed (training by the employers) to avoid the loss of jobs and to increase their labour market mobility. According to a recent evaluation (De Koning, 1989), the KRS seems to be successful as a training instrument for the unemployed. On the other hand, there is no success in stimulating the training of those already employed. Women and the smaller companies in particular are neglected.

In the Netherlands there are also nine Women's Vocational Training Centres ('Vrouwenvakschool'). Set up in 1984, they supply a large range of courses in the fields of technology (construction, metal, printing), education, services and clerical work. Women from ethnic minorities are an important target group. As stated before, the formula of these Centres is highly effective: over $90 \%$ of the women who followed a course graduate and over $80 \%$ have a job within a year. The formula is based on the concept of on-going guidance: a careful intake, group training, and instruction by female trainers. Every school has a childcare centre. The planning of the course schedule correlates with the school hours in primary education. The accessibility of the Centres by public transport and subsidies for women who want to use public transport are also important factors.

The Women's Vocational Training Centres cooperate closely with the Centres for Women and Work. Despite their success, the future of the Women's Vocational Training Centres is not 
certain. The Central Employment Board wants to integrate the Women's Vocational Training Centres with the normal Vocational Training Centres (CVs) and ordinary educational institutions. In an evaluative study of the first of these integrated structures (Gelauff-Hanzon et al, 1991), it was found that the number of successful integrations has thus far been very small. Moreover, the drop-out of trainees has risen from $10 \%$ for the Women's Vocational Training Centres to $24 \%$ for the new joint structures. According to the researchers, this loss has much to do with the typical success factors of the Women's Vocational Training Centres which were ignored in the new cooperative structures. These factors can be found at three stages of the training:

- Preliminary stage: the recruitment and selection of candidates for a training course is not limited to women who are registered as unemployed, but also include the 'hidden' unemployed who were reached by various channels, including informal methods. In the selection phase, much attention is paid to the motivation of the candidates by means of intake interviews. The ordinary CVs use mainly tests for this.

- Training stage: the content, organisation and supporting conditions of the Women Centres differ greatly from those of CVs and ordinary educational institutes. The content of each educational programme of a Women Centre is especially tailored to each group of participating women and the organisation of the programme is attuned to the time-tables of mothers with school children.

- Follow-up stage: in the training and practice period of the Women's Centres much attention is given to personal experience.

Although training can be an important factor, it should be noted here that the level of education and training is of minor importance compared to all the organisational measures that have to be taken to make the combination of housework and paid work possible. Until changes in the acts and regulations on the opening hours of shops and the tariff structures and the hours of opening of centres for childcare have taken place, the entrance of single mothers with a poor educational background is almost impossible.

\subsection{Female entrepreneurs and starting a company}

The position of female entrepreneurs is rather weak. The number of companies started by a woman is growing: in 1979 about $10 \%$ of new companies were founded by women, in 1985 this had risen to $18 \%$ (SKIM, 1985). Nevertheless there are still many barriers for women to overcome.

Under a contract from the Dutch Ministry for Economic Affairs a study was carried out of the relation between female starters and organizations offering information and advice (Renne et al, 1991). The situation in 1990 was compared with the one in 1987. Some of the conclusions:

- starters are generally in the age group of 30-39 years;

- the proportion of women among the starters had risen from $22 \%$ in 1987 to $26 \%$ in 1990;

- there is a trend from trade (retail and wholesale) to services; the number of female starters is very low in production-oriented sectors (e.g. repairs, installation, construction) and in banking and insurance; 
- the percentage of female starters with higher education has risen from $20 \%$ in 1987 to $30 \%$ in 1990;

- about $40 \%$ of the female starters had worked in a salaried profession before starting their own company. One out of five female starters is a woman returning to the work force;

- the percentage of female entrepreneurs working part-time has risen from $10 \%$ in 1987 to $20 \%$ in 1990 ;

- about $90 \%$ of the female starters ask for advice in the preparation phase, especially from the Chamber of Commerce. In general, many more women than men ask for information in the pre-starting phase, especially with regard to premises, preparation of the business plan, marketing, management and financial administration. On the other hand more men than women ask for advice in the starting phase, especially with regard to finances and business administration;

- About $35 \%$ of the women believe that they are not treated in the same way as male starters: they are not taken seriously and have to prove themselves.

A 1986 study (d'Ancona and Koopman, 1986) found the following profile of female entrepreneurs: 'The female entrepreneur has a business family background. She is relatively highly educated but not in the field in which she is starting her company. The same holds for her working experience. Mostly she is thirty years or older and married, but in practice she gets little support from her partner. Compelled by circumstances, she is starting in a more or less typical women's branch, is strongly motivated by a desire for economic autonomy and has a personal and characteristic style of management'. As in similar American research (Goffee and Shase, 1985) one of the main conclusions of this research was that two factors determine the women's entrepreneurial attitude:

- the degree to which they strive for typical entrepreneurial ideals;

- the degree to which they accept traditional man-wife patterns.

This leads to the following typology of female entrepreneurs:

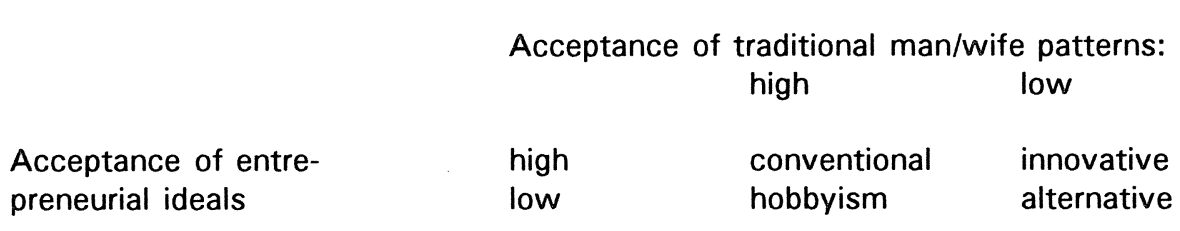

The conventional businesswomen: these women have positive attitudes to entrepreneurial ideals and the traditional man-wife patterns. Before marriage they often worked in the lower segment of the labour market. Their reason for starting a business is largely financial: to supplement the family income. These women work mainly in the service sector.

The domestic traders: these women do not strive for traditional entrepreneurial ideals such as 
growth and profit, because they are usually married with a high income partner. Their reason for starting a business is largely for fun and self-expression.

The innovative entrepreneurs: these women have highly positive attitudes to the entrepreneurial ideals of profit and growth, but they reject the traditional position of women in society. These women have ambitions, perseverance, resolution and a desire for independence. The way they manage their company is personal, democratic and non-hierarchical.

The radical proprietors: these women reject the traditional entrepreneurial ideals as well as the existing structure of society. The working environment and having their own responsibilities are more important than profit or production. The choice of a company for these women is almost a political one: an instrument in the battle against women's oppression.

Serrarens (1990) examined the personal background and the experiences, expectations and problems of a group of 100 women who had followed the course 'Eigen werk-projecten' in South Limburg. One of the striking conclusions, which was in accordance with other research findings, is the age group: a large part (about 50\%) of the women with plans to start their own company are in the age group 30-40. Most of the female entrepreneurs are highly educated. The training and education of these women is in traditional women' fields: retail and services. The main reasons why female entrepreneurs start their company in these sectors are:

- the acceptance of women in these sectors is higher than in the economic sectors which are more traditional for men;

- women start in sectors in which they have more experience, for example through a former job or through housekeeping;

- in these sectors a relative small starting budget is needed.

Almost all of the women have working experience. More than one third were receiving social welfare support at the moment they started their business. The most important motives for starting a private company are the economic independence and the (supposed) opportunities to combine work and private life. On the other hand, almost all respondents want to separate the financial risks from their family. In this respect, the attitude of women seems to be different from that of men.

Backing by partners, relatives, and more broadly, the public environment is an important factor for starters. Almost all of the female starters get only limited support from their partners. The relatives and friends of about half of the questioned women were reserved or critical of their plans or initiatives. And so were almost all of the public organisations which were asked for advice by the female starters: the Chamber of Commerce, Labour Exchange, Social Welfare Office, Community Council, and the Regional Institute for Small and Medium-sized Businesses.

There are five major categories of problems for starters: premises, credit facilities, licences and certificates, information and advice, and gathering information on market and sales potential:

1. Premises: for almost all female starters obtaining suitable and affordable premises is difficult. Many female starters begin their company in their own house, though this is not ideal. Apart from that, none of the support centres for starting entrepreneurs have special facilities for childcare. 
2. Credit facilities: almost all of the women started their company without financial support from the government. Nor did they use the capital of partners to obtain a bank credit. A recent study of the supply of small business credits $(25,000-100,000 \mathrm{Dfl}$.) confirmed this. It made clear that female starters and entrepreneurs not only ask for smaller credits, they also receive bank credits less often (Van Uxem and Kokx, 1990). Reasons for rejection are -in general- negative expectations of the cash flow (56\%), lack of private capital $(45 \%)$, and insufficient confidence in the business plan $(34 \%)$ or the entrepreneurial qualities $(32 \%)$ of the credit seeker. The last two reasons were, together with a bad presentation of the proposal, often mentioned as reasons for the rejection of requests from unemployed persons. For women, the reasons for rejection were especially the expected financial cash flow or the lack of private capital.

3. Licences: only a relatively small portion of the women need a special licence to start their own company. Most of the licences have to do with the development plan of an area. Others relate to the Nuisance Act, building regulations or establishment regulations in general.

4. Information and advice: for all starters it is difficult to obtain adequate information and advice. For women, in general, these problems are more complicated since they are less familiar with fiscal and financial matters, and the masculine behaviour codes in the business world. As pointed out earlier, many women were disappointed with the dismissive attitude and poor advice of the public institutes (City Council, Labour Exchange, Social Welfare Office). The advice of private agencies was found to be practical and useful.

5. The gathering of information on the market and sales potential of an area is also mentioned as an important barrier. Starters would like to discuss this with officials of the Chamber of Commerce with experience in regional marketing and sales and knowledge of the regional economic sectors. 
Case 1: Ms. Smith (not her real name) finished her Diploma of Fine Arts in 1984. In 1987 she started with studio facilities for artists in an old school building, followed in 1990 by courses in painting, drawing and modelling. This was done without any subsidy but with lots of enthusiasm. Nevertheless she was still dependent for her income on an unemployment benefit. Around that time, her friend, Mr. Jones (not his real name either), who is also a skilled artist, started to make kitchen benches with the terrazzo technique. This is polished concrete, with imbedded pieces of coloured marble, stone or glass. Simple applications are in floors, benches and stairs. More artistic possibilities are in garden tables, pots and tombstones.

The technique is originally from Northern Italy and was brought to the Netherlands by Italian immigrants. In recent decades the profession has dwindled, partly because the work is heavy and dusty, due to the materials, machines and procedures, and partly because of the arrival of alternative and cheaper materials. Nevertheless, there has in recent years been a kind of revival of terrazzo.

Mainly because of Mr. Jones' Italian roots, they met a retired Italian terrazzo worker in the region and were able to learn about the various techniques. They were also able to buy his old machinery for a fairly low price and he is referring his old customers to them. The studios in the old school building are rented from the City Council and have been fitted up as a workshop. Mr. Jones is doing a vocational course for a professional diploma and they are preparing a business plan to apply for a grant under the 'BZ' regulation for the support of unemployed persons who want to start a company. They still have an unemployment benefit because the earnings thus far are too irregular and too small to live from.

The first time that they started to think of a business plan was in 1991. They asked for advice from the Chamber of Commerce and received a mass of brochures. The preprinted business plan contained 40 pages of detailed questions which would be difficult even for experienced entrepreneurs to answer. There were also some questions on items which they had never thought of, for example the juridical and financial structure of the new company. Around that time Mrs. Smith gave birth to a child and the business plan with its complicated questions was laid aside. But now, a year later and after pressure from the Social Welfare Office, they have taken up the business plan with new energy and with the support of a private consultancy for questions on juridical, financial, tax and insurance issues. At present they have a small number of orders. On the one hand this gives them time to think about the company structure and to develop new techniques, models and products. On the other hand it is clear that one of the main difficulties will be the acquisition of new orders and the sale of products which they make on their own initiative. The necessary marketing and sales activities are seen distractions from what they really want to do: designing and manufacturing with terrazzo techniques.

Asked about the usefulness of the advice of the Chamber of Commerce, Social Welfare, the private consultant, and other institutions, on entrepreneurship and the starting of a business, Mrs. Smith described the private consultant as very useful on the specific, complicated issues. The attitude of the Chamber of Commerce and the Social Welfare Office was not so stimulating and helpful, partly due to their lack of knowledge on the specific topics mentioned above. Instead of this, the Chamber of Commerce gave out a lot of brochures. On the other hand, the Chamber of Commerce coordinator for starters also wrote a letter recommending that the Social Welfare Office subsidize the costs of Mr. Jones' vocational training.

Case 2: Ms. Peterson (not her real name) and her husband started a business-to-business company in a small village in 1985, with private capital and a bank loan. They were one of the few in Limburg providing a totally new service and almost all industrial companies in that line of business became clients. Her husband dealt with all technical aspects of the firm, and she did the management, business administration, new clients, and so on. The company did well and gave work to four persons. Because of rapid technical changes, an investment of 250,000 guilders for new equipment was necessary in 1988. A neighbour, working as a civil servant, suggested enquiring into the possibility of a subsidy as part of the Investment Stimulation Scheme (IPR). The management of this IPR arrangement was one of the activities of the Limburg Industrial Development Fund (LIOF, see 3.4). A preliminary investigation showed that the investment met all the conditions. So Ms. Peterson called LIOF to ask for an application form. The IPR officer told her that the IPR fund was nearly empty and, besides that, she did not satisfy the conditions: "a blacksmith in a village is not to be compared with an engineering works". After a discussion he promised her to send an application form, but this never arrived. Than the neighbour called LIOF, because he knew that there was subsidy money left, and he obtained for her an application form. Although she satisfied all the conditions, she received the form back with a critical remark and a negative decision. She sent it back with a reply, but the LIOF employee sent it back again with another critical remark. The procedure was repeated a total of three times. Finally, there was a hearing with the Provincial Deputy (who is also a Member of the Board of LIOF) as chairman. All questions were directed to the registered accountant of Ms. Peterson, who was actually the entrepreneur and the principal. The final decision was positive, but the whole procedure has been an absolutely frustrating affair. s. Peterson wanted to write an open letter to the regional newspaper but she didn't because this is not so wise for a businesswomen. 


\section{PROJECTS}

In this chapter some projects are described which may be relevant to the problems mentioned and described in the previous chapter. Most of these projects are located in the Limburg region. A few however stem from other regions.

\subsection{Recruitment and selection projects}

\subsubsection{Private agency for the recruitment and selection of women}

Goal: placement of women in management jobs.

Period: start in June 1988; re-establishment in 1992.

Organisation: private company.

Subsidy: none.

Information: Werving \& Selectie Buro voor Vrouwen Tiny Rieken, Glacisweg 49, 6212 BM Maastricht, Phone: (31)43-219607.

Explanation: as the results of many empirical research projects has shown, the recruitment and selection of women is heavily biased by the gender factor (see paragraph 4.1.). This happens at almost every stage of the recruitment process. In personal talks many women told Mrs. Rieken that they were dissatisfied, after going through many selection procedures with negative results, with the way they were treated during these procedures. They felt that they were not taken seriously, although many were convinced of their own capacities. Women are seldom offered management positions in marketing, human resources, sales and public relations in industry and business: jobs that can be done very well by women. In the first three years Mrs. Rieken discovered that women are especially needed in management positions in health care, and started a partnership with a former health care manager. Health care and public administration are the main sectors for her company.

Success indicators: in the last four years the agency has proved to be very successful. A first small advertisement in 1989, which asked for the CVs of women who wanted to be placed in the card tray, produced about 800 reactions. Since then the existence and address of her agency have become well known and many women have sent their CV. She now has a file of 1700 names and CVs. The number of requests from employers is also growing, partly because the recruiting mechanisms are changing, partly because the formula has proved to be successful. She and her partner have about 25 successful placements per consultant per year, half of these is in the health-care sector. The mean fee for this service is $15 \%$ of the gross annual salary. In the beginning she worked on a no-cure, no-pay basis, which is unusual for private employment agencies. 


\subsection{Affirmative action projects}

5.2.1. Cooperation between companies and childcare institutes, Stichting CBK, Central and North Limburg

Goal: the coordination and stimulation of company-related childcare in workers' residential areas by establishing an intermediary organization between regional employers, employee-parents and childcare institutes.

Period: Beginning with initiatives by a big company in 1988, the Stichting CBK was founded the end of 1989. In the first year 12 companies and 3 childcare institutes were involved. By mid199250 companies and 26 institutes were involved and 230 children had been found places. In the last two years at least $\mathbf{2 5 0}$ new childcare places have been created in the region.

Organisation: the foundation serves as a non-profit organisation for the companies and the labour organisations involved. The bureau has 2 employees who are occupied mainly with the arrangement of payments (reimbursements, fees, subsidies), negotiations and contracts with new customers (employers, parents, institutes). The bureau also serves as a platform and channel for information and consultation between companies and institutes.

Subsidy: the Provincial Government of Limburg gave a starting subsidy for three years. Employers receive a state subsidy for their costs of $f 2,000$ per child ('Stimuleringsmaatregel Kinderopvang 1991-'93).

Information: CBK, Mrs. Trudy Frenken, phone: (31)77-521997.

Explanation: in the Netherlands, the labour market participation of women, and of mothers in particular, is relatively low. Supporting conditions such as childcare are (therefore) poor: most schools and day nurseries are only open from 9 am- 4 pm, compared with 7 am- 6 pm in Belgium for example, where there are also possibilities for 24 hour care. In 1988 the personnel department of a large company in Venlo was confronted with a large number of requests for childcare within the company. After a small survey which proved this demand, the personnel manager contacted the regional Chamber of Commerce, to organise some small-scale market research in other companies in the region and an inventory of possible solutions devised in other regions in the Netherlands. The basic assumptions were:

- childcare has nothing to do with the core business activity of the company, but is very important for employees who are parents: the employer cannot ignore this;

- the use of the existing capacity could be improved by a better match of supply and demand of childcare services;

- childcare is required for children 0-4 years old;

- childcare is required in the area in which the worker lives.

In December 1989 the Stichting Coordinatie Bedrijfsgerichte Kinderopvang (CBK) was founded. A company which wants to participate in the CBK signs a contract and pays a fee of 1,000 guilders. From that moment CBK serves as a broker between every employee of the company and the childcare institute in the area in which they live. CBK has contracts with 26 childcare institutes in the region. This agreement includes a fixed price (of $f 14,120$ per child per year) 
and priority for company-related parents if there is a waiting list. CBK also serves as a collective cashier: it pays the childcare institutes every month and sends bills to parents and employers. The parental part of the price depends on net family income, with a maximum of $f 836$ per month. The employer pays the rest, minus the 2,000 guilders state subsidy which is received by CBK. The employers' contribution is divided if both parents work for different companies affiliated with the CBK.

Success indicators: the CBK foundation is very successful, as measured not only by the number of clients and the fact that services have been expanded in the last two years, but also by the rapidly-growing number of childcare institutes and childcare-places in the region. The area of operations is limited to the zone served by the Labour Exchange in North and Central Limburg. In the southern part of Limburg, childcare institutes are preparing a similar intermediary structure with companies.

\subsubsection{Public Bus Company, City of Maastricht}

Goal: to increase the number of female bus drivers, by special procedures for the recruiting and selection of female candidates.

Period: the affirmative action schemes were initiated in 1990 and 1991.

Organisation: the local public bus company, which is still a part of the civil service of the City of Maastricht.

Subsidy: National Vermeend-Moor Act.

Information: Public Bus Company, City of Maastricht, phone: Mr. P.M.M. Semmeling, (31)43292679, fax: (31)43-631430.

Explanation: until 1987 there were no women working in the bus services of the transport company. The increasing difficulty of recruiting suitable men, and the idea that the personnel structure should be representative of society, led the management team to the idea of recruiting women. There were no technical objections, and a positive element was the fact that more part-time chauffeurs were needed because of the more precise planning of the timetable. Early in the morning and at the end of the working day the number of buses is highest; this means that workers working full-time often enjoy 'down-time' around noon.

The recruiting criteria were lowered: any certificate at LVT level (Lower Vocational Training) was sufficient, instead of the specific LVT certificate which was in the past required for men. Also, a driver's license for private cars was sufficient, instead of the Heavy Transport licence which used to be necessary. Interest in the vacancies was enormous: over 150 responses for 810 vacant jobs. Because of the strict selection criteria in other respects, this was the minimum number of candidates required if the vacancies were to be filled.

During the introduction phase, no specific measures were taken to influence the culture of the organisation. The fact that it was made clear to all employees that the scheme had the total support of the management was very important: the loyalty and cooperation of the foremen of 
the five groups of bus drivers was especially important. They serve as a pivot between the shop floor and the executive level. It was also very important to avoid any publication in internal publications or local newspapers which might be interpreted in a negative way by the men who were already working for the bus company.

The first results of the project indicate that since the first women work for the bus company, the internal atmosphere, for instance in the canteen, has changed for the better. Two women are elected for the works council. There is one important negative factor: the absenteeism among the female workers is three times higher as among the male workers. This is mainly due to the younger women. The older women returners have the same absenteeism rates as their male colleagues. After this discovery, the medical officer of the company was asked not to give a sickness declaration in case of private problems, as sickness of the child or the baby sitter. In stead of a sickness declaration, the parent was asked to go home and look for a solid solution. To make this possible, he or she is receiving one rooster-free working day.

\subsection{Projects in the field of women and technology}

\subsubsection{Consultancy for women and technology}

Goal: to give advice and training, to select and recruit, and to organise cooperative networks.

Period: started in October 1990.

Organisation: a non-profit organisation.

Subsidy: the consultancy is funded by the Employment Board, the Sectoral Training Fund, and some government institutions.

Information: Adviesbureau Vrouw en Techniek, Drs. H. Spaan (consultant), P.O. Box 1348, 3600 BH Maarssen, Phone: (31)3465-74360, fax: (31)3465-60696.

Explanation: the Foundation for Women and Technology started the consultancy 'Vrouw en Techniek' in October 1990. This was the result of a study among technological companies around the city of Utrecht, which showed that many of these companies want to recruit and appoint women, but are unsure about how to do this. The agency activities are in the fields of:

- giving advice to sectors and companies in the recruitment and selection of women for nontraditional jobs;

- training in 'non-discriminative' selection procedures;

- the organisation of networks of small companies who want to recruit women for nontraditional jobs;

- counselling in the fields of childcare and parenting leave.

The clients of 'Vrouw \& Techniek' are the labour exchanges, business organisations and construction, transport and electronics companies, and training institutes for women.

\subsubsection{Coordination of vocational technical training projects for women}

Goal: to introduce the methods of the Women's Vocational Training Centres (see 4.4) in the vocational training centres of the Regional Employment Board and to increase the number of 
women participating.

Period: started in the spring of 1992 for a three year period. The first year's focus is on women and technology.

Organisation: the project coordinator is an employee of the Regional Employment Board but works from the Vocational Training Centre for Adults in Heerlen. The project is coordinated by a steering committee and an advisory group.

Subsidy: funded by national and regional council for Employment Affairs and the Province of Limburg.

Information: Mrs. Drs. Irma Bogers, Centre for Vocational Training for Adults, CVV Heerlen, Phone: (31)45-720494.

Explanation: this project is based on the concept of the Women's Vocational Training Centres (See chapter 4).

\subsubsection{Research and development project: 'Women in construction'}

Goal: to stimulate the employment of women in construction companies.

Period: this three-year project started in 1989.

Organisation: initiated by organisations for employers and employees in construction.

Subsidy: largely private, with some public subsidies.

Information: Project secretary Mrs. Ria Kleyzen, P.O. Box 320, 3740 AH Baarn, Phone: (31)02154-27257, fax: (31)2154-11044.

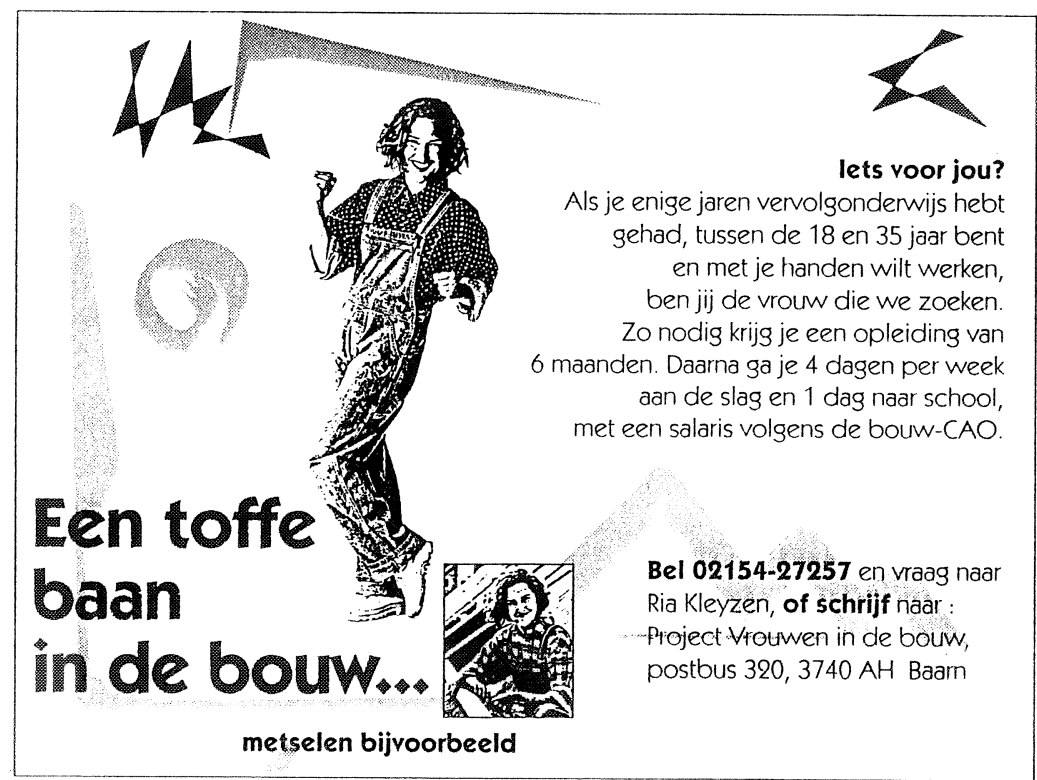

Explanation: the major goals of the project are to increase the number of women in the construction industry, by:

- gathering knowledge on social, organisational and physical factors which are important for 
women in construction occupations;

- developing methods and technology which might contribute to increasing the number of women in construction and improving working conditions.

The project is financed mainly by the Foundation for Training and Development for the Construction Industry with subsidies from the Ministries for Social Affairs and Economic Affairs. The project has three stages, which are interconnected:

- the research and development phase, which resulted in the report 'Women in construction': this ended in 1990;

- a phase with demonstration projects. These projects offer solutions for the improvement of the quality of work. These new methods and technologies are expected to be very useful for men too. Construction companies are invited for these demonstration projects on the following conditions: the company must be willing to start with some female trainees, and must have at least two female workers, who work together and are integrated in existing projects;

- a final phase with an evaluation and the promotion and dissemination of results. A request has been made for a follow-up project for another three-year period.

\subsection{Projects in the field of training for women returning to work}

\subsubsection{Labour market re-entry of unemployed single mothers, Maastricht}

Goal: labour market re-entry of unemployed single parents, mostly women, by intensive guidance and training, to jobs in areas such as local health and family care and retail services.

Period: February 1992-1995.

Organisation: joint project of the Municipal Social Welfare Office, the Labour Exchange, a private consultant and two organisations of local employers.

Subsidy: the project falls within the existing structure of subsidies for the unemployed and longterm unemployed. No supplementary subsidies for overheads have been requested.

Information: Municipal Social Welfare Office, Maastricht, Mr. Joep Drent, phone (31)43293057 or Mrs. Lucie Lintsen (section head), phone (31)43-293132).

Explanation: on the labour demand side, the local Union of Entrepreneurs in Retail Services and Board of Employers in the Health Care Sector were suffering from skill shortages, caused by a declining supply and high turnover of (female) young people. Older women, although they might be more expensive, were seen as a stable and reliable alternative. One of the main questions for these local employers was how to reach these older women. Because of some negative experiences with the Labour Exchange, the local Union of Entrepreneurs decided to ask a private consultant for advice and to develop a plan. Together with the Chamber of Commerce some possible scenarios for selection, training and placement were developed and discussed.

On the labour supply side, the city of Maastricht has about 1,100 long-term unemployed single parents, most of them women, with little or no education or working experience. Apart from individual problems such as solitude, deprivation and poor financial circumstances, this group of 
the unemployed causes a relatively high level of fixed expenses for the Municipal Social Welfare Office. Furthermore, the Social Welfare Act is to be changed, meaning that these women will have to return to the labour market. At least four broad groups of women can be distinguished:

- women of 40-50 years old, originally from Maastricht and surroundings, with older children and only primary education;

- young mothers of 20-30 years old, most of them just divorced, with young children and general or vocational education at secondary level;

- women from 30-40 years old, from the whole of Limburg and other parts of the Netherlands, with a degree in higher education but without any work experience. This group is highly motivated but also very demanding;

- a diverse group of women from abroad - Surinam, the Antilles, Morocco, Turkey, Poland and the former Yugoslavia - whose knowledge of Dutch is far from good.

The Social Welfare Office (SWO) has developed a scheme for the re-entry to the labour market of these women by means of intensive personal guidance (one or two orientation and selection talks, a training course, a period of paid or unpaid practise, and job placement). Important issues in the scheme were how to motivate these women and how to find suitable jobs.

At about the same moment the SWO was contacted by the private consultant with the plans mentioned above, which were developed for the local Union of Entrepreneurs who were facing hard-to-fill vacancies. After contacting local politicians and officials from the Ministry for Social Affairs, two agreements were signed:

- Two covenants between the City of Maastricht/SWO and the Labour Exchange on the one hand and the association of local entrepreneurs in retail services and the health board and welfare institutions on the other hand. These covenants commit the parties to do their best, for the City of Maastricht in selecting capable candidates out of a group of women returning to work, and for the local employers to provide suitable vacancies for these women.

- A contract between the local unions and the City of Maastricht/SWO. The unions receive a reimbursement of $f 750$ for every woman who is placed in a traineeship, and again for every woman who is placed in a vacancy after the training period. The unions in turn have contracted with the consultant to carry out these activities.

All of the 1,100 women received an information letter and brochure in March '92, which explained the project and the supporting facilities in terms of finances, training, childcare, and assistance in locating traineeships and vacancies. This written information, together with the discussion of the project in the twice-early meetings of each client with an SWO official, created a good response, especially in the group of women with higher education.

Problems were expected to arise because of the lack of facilities for childcare. Therefore, a number of places were reserved at the local childcare foundation, KIM, which is financially supported by the City of Maastricht. Arrangements were also made with the Labour Exchange to subsidise training. The main costs of the project are the salaries of three social workers for a one-year period and the costs for childcare, training courses, and the fees for the private 
consultant.

First results: two months after the start of the project two groups have started with a basic course in general education. In addition to this, groups have started training for retail services (21 women) and for the health care and welfare sector (22 women). After the first six months, in the period from March to August 1992, a total of 309 persons were asked to come to the SWO or came on own initiative. From these 309, 305 were women, 172 were older than 35 years, 14 had a foreign nationality and 20 persons had almost no educational background. Out of these 309 persons, 10 persons were not willing to be trained or to work and 81 were not able to be trained or to work because of a weak mental or health situation. A total of 175 persons were placed in a general or vocational training or guidance course or an application course. Nine people are already working. As in some other projects in the City of Maastricht, (the Fire Brigade, public transport) the limited availability of childcare was said to be a problem. Although the policy for the scheme stated that places for childcare were available for participants, in practice this turned out to be not always the case. Only after the first half year was the KIM organisation able to make more places available.

Reasons for success: The Social Welfare Office has a strong financial incentive to achieve success with these plans, because the long-term unemployed cause recurring expenses which are partly paid from local community funds. The Labour Exchanges lack this motivation. There are also long-standing and confidential personal relations between the clients and the SWO officials.

\subsection{Projects for those starting businesses}

\subsubsection{Guidance, training and advice for female starters, Heerlen}

Goal: to support female starters and entrepreneurs.

Period: the 'Vrouw en Werk Winkel' in South Limburg was founded in 1981.

Organisation: the 'Vrouw en Werk Winkel' is a non-profit organisation.

Subsidy: since 1987, by subsidies from the Ministry of Social Affairs. Since 1990 by the tripartite Board for Regional Employment Policy.

Information: Women and Work officer for female starters (Mrs. Dorine Hulshof, phone (31)45710079.

Explanation: the 'Vrouw en Werk Winkel' undertakes the following activities on the theme 'female entrepreneurs':

- supporting women by structuring business plans;

- noting barriers and misgivings;

- guidance in making a business plan and carrying out marketing research;

- advice on financial matters (bank loans, subsidies);

- advice on laws, regulations and other legal matters;

- the guidance and training of women on the items mentioned above; 
- trying to set up networks or sharing information about existing networks.

The 'Vrouw en Werk Winkel' gives orientation courses for women planing to start a business. As a result of these orientation courses some women decide to stop. About half go further with a course for female starters or for a retailer's diploma. In the annual report for 1990 the following business ideas were mentioned:

- travel agency;

- bureau for private health care;

- translation agency;

- private establishment for childcare;

- retailing: photographic shop, music store, specialised bookshop, clothes, gifts;

- design studio for fashion.

Recently the regional Council for Employment Affairs, which finances the 'Vrouw en Werk Winkel', has ordered them to stop offering guidance, advice and training for female starters and entrepreneurs.

\subsubsection{Contact day and almanac for businesswomen in Limburg}

Goal: compilation and presentation of an almanac with information about female entrepreneurs in the Limburg region.

Period: preparation in 1992, day: 5 Oct. 1992.

Organisation: Vrouw en Werk Winkel.

Subsidy: European Fund for Regional Development (EFRO).

Information: Mrs. Dorine Hulshof, phone (31)45-710079 (see above, 5.5.1).

Explanation: female entrepreneurs and starters have their own specific problems (see 4.5.). In Limburg there are an estimated 1,200 female entrepreneurs, largely unknown and invisible. The first idea was to trace these women and bring them together by organizing a conference for businesswomen and starters, with information stands and a fair where women could present their business. To ensure that this day would not be of interest only for starters seeking advice, but also for the already successful businesswomen, the idea of a fair was rejected. The main goal of the day was to do something for the image of female entrepreneurs. The almanac, a photo book with a short description of the main activities, seemed a better way to show that women are serious and successful entrepreneurs in a wide range of sectors. Presenting this almanac on a contact day with many successful female entrepreneurs and interesting speakers proved successful.

\subsubsection{Bureau for small-scale employment, Heerlen}

Goal: to give advice and guidance to those starting or considering starting their own business, especially to the unemployed, from the beginning of the planning stage until the start.

Period: the bureau was founded in 1986 as a private initiative. 
Organisation: there are 3 part-time consultants who work for the Foundation for Employment projects, which is financed by 4 participating municipalities.

Subsidy: no special subsidy. The foundation is funded by the 4 participating municipalities.

Information: Foundation for Employment Projects, Office for Small-scale Employment, (Stichting Werkgelegenheidsprojecten, Bureau Kleinschalige Werkgelegenheid), Raadhuisplein 18, 6411 HK Heerlen, phone: (31)45-718601.

Explanation: as a reaction to large-scale unemployment, local governments, Municipal Social Welfare Offices and the Labour Exchange in the South-east of Limburg (around Heerlen) are trying to stimulate self-employment. People with plans and opportunities to start an enterprise get advice, for instance in developing a business plan. All consultations are free of charge. For the unemployed who want to start an enterprise there is the so-called Bijstandsbesluit Zelfstandigen (Resolution Governing Social Welfare for the Self-employed Starting Businesses), a government arrangement which offers financial possibilities. If the business plan appears sustainable and economically viable, this arrangement allows the starter to keep the social welfare benefit for a period of a half or full year and/or the possibility of credit up to a maximum of 40,000 guilders. The office has about 250-300 clients a year, of whom 25-30\% are women. In 1991 there were 265 clients (35\% women), 47 of whom actually started a business (13 women). The larger part of the starters are long-term unemployed persons, with vocational education at lower or intermediate level and between $20-40$ years old. About $50 \%$ of the starters are active in the service sector, and $20 \%$ in catering services.

\subsubsection{Mama Cash: credit facilities for female starters}

Goal: provision of financial support for women's projects and companies.

Period: started in 1982 as a private initiative.

Organisation: Mama Cash is a non-profit foundation.

Subsidy: started with private capital from a substantial legacy.

Information: Mrs. Marjan Sax, phone: (31)20-6893634.

Explanation: Mama Cash is a private fund which gives financial support to women's projects and companies. For female entrepreneurs who cannot receive a normal bank loan because of a lack of private capital, it supplies guarantees up to $f 25,000$ in support of loan applications. Mama Cash itself does not provide loans for companies. Support is only for initiatives which cannot receive support from other institutions. In practice, this means that feminist-oriented projects in particular are supported. Important conditions for support are: financial attainability, a feminist approach, and it must be a really innovative activity. Mama Cash also provides subsidies or loans for projects in the field of media, arts, presentations, congresses and courses, and various activities in the field of third world and women's liberation.

\subsection{5. 'Mentorscope' Foundation and bureau, Haarlem}

Goal: to supply independent and experienced counsellors as mentors for female entrepreneurs. Period: started in 1990. 
Organisation: a small office with two employees serves as a broker/ intermediary. The foundation has an Advisory Board with eight 'bigshots', and a Board of Management with three supervisors.

Subsidy: the foundation is a non-profit organisation, with a starting subsidy from the Ministry of Economic Affairs. It receives legacies, donations and asks a small amount for every consultation to cover travel expenses for the counsellor.

Information: Mrs. M. van Brunschot, Nieuwe Gracht 37, 2011 NC, Haarlem. Phone: (31)23159179, fax: (31)23-329164.

Explanation: if a female entrepreneur wants objective advice from an independent and experienced businesswoman she contacts the agency. Within a couple of days the selected mentor calls back for an appointment. The meeting usually takes place within the client's company. The initiative came from a former female director of a large Dutch company. She arranged a special consulting hour for female entrepreneurs in the Chamber of Commerce in the City of Haarlem. Because of its great success, the idea has grown to the organisation of a network of experienced businesswomen who can serve as sparring partners to discuss business problems with. The Mentorscope Foundation was founded in 1990, and in one year, about 40 women with business experience in various fields provided information on legal, technical, international, commercial, personnel or financial issues. The councillors receive 50 guilders per consultation.

The bureau has been active for only one and a half years. In the first eight months of 1992 around sixty mentorships were arranged, with a slight decline in the last months due to the holidays. The requests come not only from the Western region of the Netherlands but from all regions and sectors. Most of the women are referred by regional Chambers of Commerce. 



\section{RECOMMENDATIONS}

This last chapter contains a description of some of the main problems that were investigated in the ATHENA project. The description of each problem is followed by a short recommendation or proposal for further action. The definition of the problems as well as the formulation of the recommendations are based partly on the research reports which were used for chapter 4 , as well as on remarks that were made during visits and interviews in composing the profiles of the projects described in chapter 5 . Some of the ideas for recommendations were born during the visits to Berlin and Wales, and some were discussed in meetings with local women's organisations. Of course the author remains responsible for this last chapter.

\subsection{General recommendations}

\subsubsection{Regard for equal opportunity affairs in formulating regional employment policy}

The problem: the organisations in Limburg dealing with women's issues are strongly focused on their own activities, preparing conferences, holding discussions with similar organisations and writing articles for their own magazines. Their effectiveness, in terms of real successes and innovative actions, seems rather low. Access to decision-makers, goal-oriented cooperation and pragmatic coordination are lacking.

The recommendation: these organisations should, firstly, direct themselves more to the activities of public organisations which could be of real importance for them, secondly, try to keep equal opportunity affairs on the public policy agenda, and thirdly, try to influence the decision-making processes of public bodies.

In order to exert effective influence in the field of employment and equal opportunity the regional organisations for equal opportunities for women should claim a seat in, for example, the Foundation for Employment and the Labour Market in Limburg (Stichting Werkgelegenheid en Arbeidsmarkt Limburg, SWAL) or the Foundation for the Labour Supply in Limburg Agriculture (Stichting Arbeidsvoorziening Limburgse Land- en Tuinbouw). Furthermore, it is necessary for the more progressive organisations such as Vurore and Vrouw en Werk to cooperate with the more traditional women's organisations such as LVR and LVB and their representatives in provincial politics. It is important for these organisations to create an effective programme, like the 'Fair Play' Consortium in South Wales. This should pay special attention to the 'ear-marking' of public subsidies for equal opportunity goals.

\subsubsection{A regular paragraph in the annual provincial labour market programme}

The problem: the position of women on the Limburg labour market is a rather small topic in provincial policy and political discussions. This is partly caused by the 'invisibility' of the women in the regional labour market statistics. 
The recommendation: each year the Province of Limburg publishes an evaluation of the labour market policy of the province, covering all projects financed by provincial funds. Members of the Provincial Council should be lobbied so that every year special attention is given to the position of women on the Limburg labour market, the projects which have been developed and completed, and the quantitative progress that has been achieved. This would also force the Province to gather and present figures and key statistics on this issue on a regular basis, something which is lacking now.

\subsubsection{Organisations for women and work should make more use of free research capacity}

The problem: one important task for organisations who are active in the field of women and work is to keep issues on the public agenda. One way to do this is to stimulate local and regional research, to get free publicity with the results and to write or to initiate policy proposals. The problem of almost all of these organisations is that they don't have funds to finance research.

The recommendation: these organisations should try to make more use of one the main tasks of institutes for higher education: the public service function. Universities and institutes for higher vocational education have research capacity in terms of students who are looking for an interesting item for a doctoral thesis, as well as the regular staff. Sometimes they even have funds of their own: for example the University of Limburg and its faculties have a budget for applied research in equal opportunities and women's affairs. Intermediation by the Wetenschapswinkel, Transferpunt or the faculties' research bureaus is necessary and available. Items for further research could be: to investigate the opportunities for and willingness of a public investment bank in Limburg to reserve funds for female starters (see further); regional marketing research and strategies for starters; effectiveness of a policy, to be formulated by the Province of Limburg or the City of Maastricht, stipulating contract compliance when letting contracts for supplies or services; cross-border and international legal research on the necessity of European legislation on aspects of equal opportunities, etc..

\subsubsection{Support for a brief regional newsletter on women and work}

The problem: there is a need for brief announcements and information on the problems, activities and projects of the organisations involved with women and work.

Recommendation: a quarterly newsletter of two to four pages, with only essential information (announcements, addresses and phone numbers, short description of the targets and plans for conferences, courses, projects or measures, together with a photo of the responsible officer or institute) could be much more effective than meetings and deliberations with the same goal. See for example Network News, the Newsletter of the Glamorgan Businesswomen's Network, and the Fair Play Newsletter of the Chwarae Teg Consortium in South-Wales. 


\subsection{Recommendations on recruitment and selection}

\subsubsection{More attention for the position of women within the provincial civil service}

The problem: the Province of Limburg has a poor performance in the field of internal equal opportunity affairs. This is indicated by, for example, the allocation of higher positions within the provincial organisation. Out of a total of 744 persons (May 1991) in the highest positions (Director, or Head of Department or Bureau), there is only one woman, who is head of the Department for Personnel Management.

Recommendation: the Province should report yearly on the progress that has been made. There are new possibilities because the new Provincial Deputy for Personnel Affairs is a woman, the first who has ever been a member of the Provincial Council.

\subsubsection{Business Counsellor for Equal Opportunity Affairs}

The problem: as shown by the research described in Chapter 4 and our own small follow-up survey among 16 Limburg companies, the concept of affirmative action does not work without commitment. The Province of Limburg has no means of influencing this situation by regulation.

Recommendation: the Province of Limburg should finance a Business Counsellor for Equal Opportunity Affairs, analogous to the five Business Counsellors for Training who work in the province of Limburg. These five advisors work for the Chambers of Commerce and the Regional Institute for Small and Medium-size Enterprises and are partly financed by the Province of Limburg and the European Social Fund (total costs 1.7 million guilders.). The initiative for this project was taken by the Limburg Union of Employers and the Limburg Organisation for Independent Entrepreneurs. The Business Counsellor for Equal Opportunity Affairs should be guided by a committee of representatives of the Province of Limburg and organisations for equal opportunity, with a regional female entrepreneur as chairperson. The Business Counsellor for Equal Opportunity Affairs should cooperate with the five Business Counsellors for Training and with institutes such as the Limburg Centre for In-company Training and the Technology Training Centre. Whether the counsellor should be a man or a woman, and the personal profile and main tasks, should be carefully discussed. The project should be prepared by a steering committee of representatives of organisations for women and work. Evaluation of the activities of the Business Counsellor for Training should be arranged.

\subsubsection{Increase the supply and use of childcare facilities}

The problem: the facilities for childcare are very poor. Not only is the number of vacant places much too small (with a waiting list of two years), but also the accessibility and opening times of many childcare establishments are bad. For many parents with a relatively small income, the costs of professional childcare institutions are too high. 
Recommendation: as shown by the Stichting Coordinatie Bedrijfsgerichte Kinderopvang (CBK, see 5.2.1.) the formula of bringing together the three parties involved in childcare (parents, nurseries and companies) could be very useful for other regions too. Therefore, the provincial deputy of Economic or Equal Opportunity Affairs should encourage organisations such as Kinderopvang in Maastricht (KIM), the Chamber of Commerce, or the Regional Employment Board to produce a brochure with information on the CBK project in the Venlo region and initiate small-scale market research to make an inventory of local needs in the coordination of childcare facilities.

\subsection{Recommendations on women and technology}

\subsubsection{Encouragement of women and girls in technical education}

The problem: although women have reached the same levels of educational attainment as men, they are still under-represented in technical courses. This adds to the shortage of technicallytrained persons on the labour market.

Recommendation: in the Braams and Meesters report (1991, see 4.3.) the following policy suggestions were made:

* In primary education more attention should be paid to the arithmetic and technical skills of girls. A project like this outside school already exists: Technika 10, a technical hobby club for 10-12 year old girls.

* Introduction of the subject 'technology' in general education could also add substantially to the technical skills of girls.

* Girls who have the aptitude for technical subjects should be explicitly encouraged to enter technical education.

* Technical schools should be more critical in selecting companies for the girls' practical learning period: many girls have negative experiences during this period. This can in part be avoided.

\subsubsection{Encouragement of women in technical companies}

The problem:

* Many employers seem not to be prepared to execute affirmative action programmes, although they are very satisfied with the performance of the women they are presently employing in technical capacities. They are also aware that these women have had a difficult start.

* Many employers expect female workers to leave after a couple of years because of children. For many companies this is a reason to pass over women for promotion or career-oriented training. On the other hand, many women want to continue their job eventually, after a period of part-time work. 
Recommendation: in the Braams and Meesters report (1991) the following suggestions were made:

* It is very much in the interest of companies and women that extra attention be paid to the selection and hiring of women for technical functions.

* The combination of parenthood and work for women and men should therefore be facilitated. Women want to stay at work, often part-time. The idea of employers that women will stop working anyway seems to be groundless. It is more likely that women are forced to stop work by lack of sufficient facilities. Part-time work, flexible working times, childcare 124 hours if necessary), re-entry arrangements, refresher courses and the like can contribute much to the situation.

\subsubsection{Change the public information campaign on women and technology}

The problem: in a recent public information campaign to encourage girls to choose a technical training and occupation, girls were shown in technical jobs which seemed heavy and dirty.

Recommendation: in reality, this is inaccurate, and it does not encourage girls to choose technical careers. In the study by Braams and Meesters (1991), women were found to work in semi-technical jobs such as designing, process operating, and middle management. The public information campaign on women and technology should therefore be changed.

\subsection{Recommendations on the training of unemployed women}

\subsubsection{Improve aggregated information on the unemployed}

The problem: the Social Welfare Office has a great deal of information on its clients at an individual level. But there is no comprehensive aggregate information on the education and work experience available. This kind of information could be very useful for the officials of the Social Welfare Office or the Labour Exchange in developing a training strategy for the long-term unemployed.

Recommendation: an automated programme at a local level for the numerical classification of background variables of the long-term unemployed should be developed. Information on personal characteristics (age, gender, ethnicity), educational background, working experience and family situation should be made available at an aggregated level to support policy-making.

\subsubsection{One integral and cooperative information and motivation campaign on women and work}

The problem: some of the studies and projects which were described in chapters 4 and 5 show that there are ways of bringing unemployed women back onto the labour market. Some of the key concepts are intensive personal guidance and attention for necessary supporting conditions such as accessible childcare. The availability of suitable vacancies and the provision of general or vocational training are also important. The possibility of the unemployed starting their own 
company should also be kept constantly in mind.

One barrier in the process of bringing unemployed women back to the labour market is that many of the organisations involved have a closed-shop attitude towards each other and a calculating or uninterested attitude to the prospects and problems of the women involved: if they do not fit into the target group of clients they are referred to other organisations, without knowing what exactly these other organisations are doing. The Vrouw en Werk Winkels (see 5.5.1) and the training and guidance project of the Social Welfare Office (5.4.1) are successful largely because they really pay attention to the position and the background problems of their clients, and the solutions which may be offered by other organisations.

The New Opportunities for Women (NOW) programme has high ambitions for the creation of trans-European networks between women's organisations. This must be called 'ambitious' as long as the workers in these organisations, even in one city, hardly know each-other's activities. Therefore it would be fruitful to start with local and regional networking programmes for all organisations involved with aspects of women and work.

Recommendation: to develop a motivation programme for all women within those quarters of the City of Maastricht with many unemployed women. This programme should be actionoriented, and therefore, like the Tennessee Valley Authority and New Deal of President Roosevelt and the Delta Plan in the fifties, pay less heed to the existing areas of competency. Therefore the cooperation of all the institutions working in the field of 'women and work' is necessary: the Labour Exchange, Social Welfare Office, the Maastricht City Council, Vrouw en Werk Winkel, the Chamber of Commerce, Union of Local Employers, training institutes, etc. A special project manager should be appointed, accountable to the Mayor and the Council of the City of Maastricht.

This cooperative union should first produce a brochure which is clear and comprehensive, on all opportunities for training and work. The intensive guidance service of the Social Welfare Office and the Centre for Women and Work in Maastricht should particularly be mentioned. The second stage of the project would be the production of one mailing list with the addresses of all women who are registered as unemployed, living from social welfare benefits, or seeking work. The brochure must be mailed to the entire list. There should be an incentive structure both for the participants in training schemes and for those offering traineeships. As a third stage of the project, the training and guidance project of the City of Maastricht (see 5.4.1) could be extended.

\subsection{Recommendations on female starters}

\subsubsection{Restructure the gathering of statistics on companies to include the gender factor}

The problem: at the national as well as at the international level, there are hardly any statistics on female entrepreneurs available. The annual ERBO survey of all Dutch companies commissioned by the Chamber of Commerce does not contain any questions on the number of 
female entrepreneurs, female employees, etc.

Recommendation: to incorporate gender as an extra question in the annual ERBO survey and when registering and up-dating information on the Company Register. Both tasks are performed by the regional Chambers of Commerce.

\subsubsection{Special counselling hours for women with the regional Chambers of Commerce}

The problem: the Chambers of Commerce are oriented especially towards the usual questions of starters with a developed business plan, who are able to work full-time on their future business. Many women want to start gradually, especially when they have children to take care of. The Chambers of Commerce in Haarlem, Amsterdam and Enschede have therefore started with consulting hours especially for women. These were found to be a great success. A research project by the Chamber of Commerce in Haarlem shows that:

- a special counselling hour for women doubled the participation rate in the space of two years;

- better preparation of starters leads to a quicker start, especially among the female starters.

Recommendation: the Chamber of Commerce in Limburg should follow this initiative and install a special consulting hour for female starters. An additional reason for urgent attention to this is that the Regional Employment Board has ordered the Vrouw en Werk Winkel of South Limburg to stop its guidance and training activities for female starters as at 1 January 1993, because they should concentrate on training and vocational guidance.

\subsubsection{Reservation of LIOF funds for female starters}

The problem: as was concluded in the studies mentioned in paragraph 4.5., it is more difficult for female starters and entrepreneurs to receive a bank loan. There are some arrangements for starters: for unemployed starters there is the BZ regulation (see 5.5.3.); for young starters from some universities there are temporary positions, for investments from bigger companies there is the national subsidy arrangement IPR etc. The European Commission has a small subsidy arrangement for Local Employment Initiatives for Women, especially for women who want to start their own company. Of course, there are many private banks for loans. The problem is, that most of the women do not have private capital or wealth to serve as a guarantee for bank loans. This means in practice that it is almost impossible for these women to finance the activities that are necessary for the starting of a company: for example a small market-audit or study of demand.

Recommendation: the public investment bank in Limburg (LIOF: set up by the central Dutch government and the province of Limburg to finance the restructuring of the economy after the closing of the coal mines, see 3.5) should create a special fund for investments for female starters.

It is also possible for LIOF to make a specific development strategy for female starters. 
Elements of this plan could be the ear-marking or reservation of funds for female starters or to ease the loan conditions for women, the development of a local support centre for female starters, and the installation of a female counsellor for female starters and entrepreneurs.

\subsubsection{Improve the orientation, guidance and advice structure for starters}

The problem: as can be seen from recent regional research (Serrarens, 1990) the advice structure for female starters is vague and inconsistent: many institutions were found to have a negative attitude. In the existing policy for the advice and guidance of starters, a large place is reserved for the regional Chambers of Commerce. As long as they are financed by contributions from the regional trade and industry, starters will remain a minor priority. In general the need to obtain a retailer's diploma is a hinderance for many people, especially for ethnic minorities, in starting their own companies. At the moment there is a public debate between the Ministry of Economic Affairs and the sectoral organisations regarding the need for this diploma. The organisations for women and work should try to influence this debate;

Between the first idea of starting one's own business and the writing of a mature business plan comes a long process of orientation and research. This process has several stages, in which different organisations are involved.

1. the first idea: entrepreneurial attitude

- Vrouw \& Werk Winkel

- Social Welfare Office, Labour Exchange

- schools, universities

2. second orientation: general questions - Chambers of Commerce

- Office for Small Scale Employment

Then to write a mature BUSINESS PLAN for funding, loans, licenses

3. concrete information: specific questions - LIOF, private banks

- private agencies

4. starting-off phase: coaching/ mentorship - regional Mentorscope

Recommendation: the existing information and advice structure is not suitable for concrete and specific questions. Organisations such as the Office for Small scale Employment and private consultancy agencies are therefore necessary and should receive financial incentives for offering orientation help and information for female starters. The Province of Limburg should therefore initiate a study of the desirable diversity of the information and advice structure in Limburg, followed up by policy as required. In this it is important that several stages in the process should be distinguished. Special attention should be paid to the first stage. It is also important that more attention should be given to the starting of a business in courses of general and vocational education. 


\section{LITERATURE}

- In general:

Bruyn-Hundt, M. (1988) Vrouwen op de arbeidsmarkt. Nederlandse situatie in de jaren tachtig en negentig. SCALA, Utrecht.

Camp, H. van (1988), Werken aan werk voor vrouwen. Een literatuurverkenning, ETIL, Maastricht.

Felling, A. en J. Peters (1988), Het cultuurpatroon van de katholieke en onkerkelijke Limburger in het midden van de jaren tachtig, in: E. Hermans and T. van Hoogen (eds.), Van katholiek Limburg naar katholieken in Limburg, UTP, Heerlen, pp. 25-84.

Hanraets, P.C.M., (1991), Arbeidsmarkt voor vrouwen in Limburg. Recente veranderingen in hoofdlijnen. ETIL, Maastricht.

Hofstede, G.H. (1987), Gevolgen van het Nederlanderschap. Inaugurale address, University of Limburg.

Hofstede, G.H. (1980), Cultures Consequences. International Differences in Work-related Values, Sage, Beverly Hills.

Schreuder, O. (1989), Limburgse cultuur, proeve van een diagnose, in: T. van Hoogen (ed.), Tussen afbrokkeling en vernieuwing, UTP, Heerlen.

Soeters, J. and A.J.A. Felling (1990), Het eigene van Limburg, in: J. Soeters, H. Spoormans, R. Welten (eds.), Het Nieuwe Limburg, pp. 277-297.

Tweede Kamer der Staten Generaal, vergaderjaar 1988-1989, Maatschappelijke positie van meisjes en jonge vrouwen. Beleidsnota. Vergaderstuk 20939.

Wolfs, G. (1992), Firm internal labour markets in the Netherlands. A contract theoretical approach. Dissertation, 92-6, Faculty of Economics and Business Administration, University of Limburg, Maastricht.

- On women and recruitment and selection:

K.W.H. van Beek (1992), Kiezen uit sollicitanten, concurrentie tussen werkzoekenden zonder baan, WRR Voorstudies en Achtergronden, nr. V 74, SDU-Uitgeverij, Den Haag.

M.A. Jacobs et alia (1992), Werving en selectie van vrouwen bij de politie. Zonder maatwerk geen uniform. In: Tijdschrift voor Arbeidsvraagstukken, nr. 2, pp. 22-38. 
A. van Vianen, and T. Willemsen (1992), The Employment Interview: the Role of Sex Stereotypes in the Evaluation of Male and Female Job Applicants in the Netherlands. In: Journal of Applied Social Psychology, 22, 6, pp. 471-491.

\section{- On affirmative action within companies:}

BiZa (1991), Overheid en Arbeidsmarkt 1991, Ministerie van Binnenlandse Zaken, Den Haag.

Claessens, I. (1989), Het emancipatiebeleid in Limburgse bedrijven. 'Er moet geen gezeur zijn over kinderen afhalen en zo...!', Vurore publication nr. 4, Roermond.

Jacobs, M., et al. (1990); Werving en selectie van vrouwen bij de politie. Zonder maatwerk niet in het uniform, in: Tijdschrift voor Arbeidsmarktvraagstukken (6), 2, 22-37.

LPEC (1990), Landelijke Politie Emancipatie Commissie, Politie Emancipatieplan.

LPEC (1992), Landelijke Politie Emancipatie Commissie, Resultaten onderzoek Bureau Intomart.

H. Maassen van den Brink et al. (1992), Vrouwen over werk, University of Amsterdam.

SoZaWe (1992), Emancipatie in arbeidsorganisaties. Dienst Collectieve Arbeidsvoorwaarden en Loontechnische Dienst, Ministerie van Sociale Zaken en Werkgelegenheid, Den Haag.

- On women and technology:

Braams, M. and M. Meesters (1991), Aanpassen en jezelf blijven. Schoolloopbanen en werkervaringen van meisjes met een technische opleiding. OSA-Werkdocument W-86 (with English summary 7 pages), Den Haag.

Hanraets, P.C.M. and H. van Camp (1991), Vrouwen in techniek. Een studie naar de Limburgse situatie. ETIL, Maastricht.

Vaas, S. and M.B. Berndsen (1990), Vrouwen in de bouw, Stichting Bouw Research, Rotterdam.

- On the effectiveness of training for adults and women:

Gelauff-Hanzon, C.W., et al. (1991) Samenwerken aan vrouwenvakscholing. Een onderzoek naar de samenwerkingsverbanden tussen vrouwenvakscholen en andere opleidingsinstituten, University of Leiden.

Gelderblom, A. and A.C.H. Hammink, (1991), Rendement in volwasseneneducatie, Nederlands Economisch Instituut, Rotterdam. 
De Koning, J., et al. (1989), Landelijke Evaluatie Kaderregeling Scholing, Nederlands Economisch Instituut, Rotterdam.

- On female starters:

Koopman, G. and M. Verstappen (1986), Zakenvrouwen, in: Intermediair, pp. 59-63.

Renne, A.C.H., M.H. Stijnebosch, and H. Ruyter (1991), Vrouwelijke ondernemers, Stichting voor Ruimtelijk onderzoek, Utrecht.

Serrarens, J. (1990), Vrouwelijke ondernemers in zuid- en midden Limburg. Steunpunt Vrouw en Werk, Sittard/Heerlen.

SKIM (1988), Vrouwelijke ondernemrs, Ondernemerschap, ondersteuningsbehoeften, ondersteuningsaanbod. (Statistisch Kwalitatief Industrieel Marktonderzoek), Rotterdam.

Van Uxem F.W. and A.C.W.M. Kokx, (1990); Onderzoek behandeling kleine zakelijke kredieten. Economisch Instituut voor het Midden- en Kleinbedrijf, Zoetermeer.

- On projects:

Politie Emancipatieplan (1990), Ministerie van Binnenlandse Zaken, Den Haag.

Werkgroep Emancipatie Brandweer (1991), De brandweer vraagt vrouwen. Advies inzake de bevordering van de emancipatie binnen het brandweerwezen. Ministerie van Binnenlandse Zaken, Direktie Brandweer, Den Haag. 


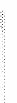




\section{LIST OF INTERVIEWS}

\section{General interviews:}

- Mrs. S. Arda, Directrice of Vurore, Instituut voor Emancipatieontwikkeling Limburg, Roermond;

- Mrs. A. Bruins, Executive worker, equal opportunity affairs, Social Welfare Department, Maastricht City Council;

- Mrs. B. Kruijtzer-Mulders, Section Head, Council of Limburg Women (LVR);

- Mrs. M. Meijers, Provincial Government of Limburg, Office of community welfare, equal opportunity affairs.

Interviews on women returning to work

- Mr. J.J. van Bergermeer, Adviesbureau Van Bergermeer, Maastricht;

- Mr. J. Drent, Department of Social Welfare, Maastricht City Council;

- Mrs. J. Ramakers, Department of Social Welfare, Maastricht City Council;

\section{Interviews on affirmative action schemes}

- Mr. A. Fiviez, deputy commander, Maastricht Fire Brigade;

- Mr. Semmeling, Executive Officer, Personnel Dept., Maastricht Bus Service;

- Mrs. M. Montsanto, Steunpunt Emancipatie Brandweer, Ministry of Internal Affairs

- Mrs. Badeloch Tangelder, Directie Politie, Ministry of Internal Affairs

\section{Interviews on childcare}

- Mrs. T. Frenken, Stichting Coördinatie Bedrijfsgerichte Kinderopvang Noord-Limburg, Venlo;

Interviews on female starters

- Mrs. D. Hulshof, executive worker Steunpunt Vrouw en Werk, Heerlen;

- Mr. G. Smit, Bureau Kleinschalige Werkgelegenheid, Heerlen;

- Mrs. M. Smeets, Instituut Mens \& Arbeid, Heerlen;

- Mrs. T. Rieken, Directrice Werving en Selectiebureau voor Vrouwen, Maastricht;

- Mrs. E. Rongen, Atelier voor Terrazzo-vormgeving, Maastricht;

- Mrs. G. Stelpstra, Director, Bureau Mentorscope, Haarlem;

- several female starters;

Interviews on women and technology

- Mrs. I. Bogers, CVV Heerlen;

- Mrs. R. Kleyzen, Project leader 'Vrouwen in de Bouw', Baarn;

- Mrs. Drs. H. Spaan, Women and Technology advisor, Maarssen;

\section{Interviews on project proposals}

- Mrs. E. Appelo, Instituut voor advies, scholing en vorming De Driekant, Valkenburg aan de Geul;

- Mrs. M. Jacobs, executive worker, Employment and Training, Vurore;

- Mrs. B. Braun, Mitarbeiterin Gleichstellungsstelle Mönchengladbach. 